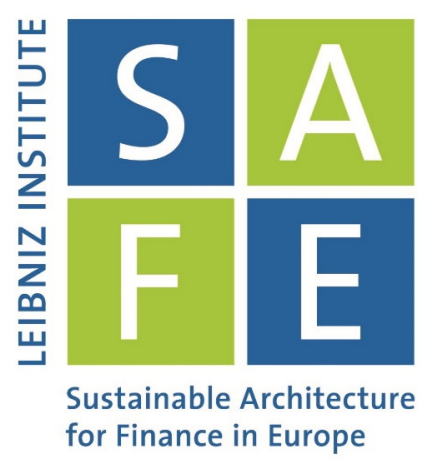

Gyozo Gyöngyös | Judit Rariga | Emil Verner

\title{
The Anatomy of Consumption in a Household Foreign Currency Debt Crisis
}

SAFE Working Paper No. 332 | December 2021

\section{Leibniz Institute for Financial Research SAFE}

Sustainable Architecture for Finance in Europe 


\title{
The Anatomy of Consumption in a Household Foreign Currency Debt Crisis*
}

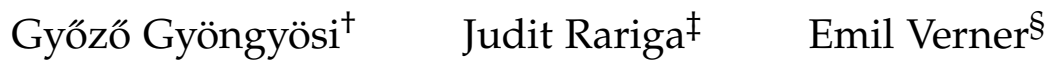

December 2021

\begin{abstract}
This paper studies the consumption response to an increase in the domestic value of foreign currency household debt during a large depreciation. We use detailed consumption survey data that follows households for four years around Hungary's 2008 currency crisis. We find that, relative to similar local currency debtors, foreign currency debtors reduce consumption approximately one-for-one with increased debt service, suggesting a role for liquidity constraints. We document a variety of margins of adjustment to the shock. Foreign currency debtors reduce both the quantity and quality of expenditures, consistent with nonhomothetic preferences and "flight from quality." We find no effect on overall household labor supply, consistent with a weak wealth effect on labor supply. However, a small subset of households adjusts labor supply toward foreign income streams. Affected households also boost home production, suggesting a shift in consumption from money-intensive to time-intensive goods.
\end{abstract}

\footnotetext{
${ }^{*}$ We are thankful for feedback from Mark Aguiar, Tamás Briglevics, Hans-Martin von Gaudecker, Benjamin Hemingway, Miklós Koren, Jan Pieter Krahnen, Søren Leth-Petersen, Krisztina Molnár, Jonathan Parker, Ádám Szeidl, Christine Zulehner, and participants at the CEPR International Macroeconomics and Finance Conference, CEPR Conference on New Consumption Data, European Economic Association Conference, Verein für Socialpolitik Conference, 3rd Baltic Economic Conference, International Association of Applied Econometrics Conference, Centre for Economic and Regional Studies, EconTribute-SAFE Household Finance Workshop, Central Bank of Hungary, Arizona State University, and HKUST. We thank Elisabeth Beckmann and the Austrian National Bank for the Euro Survey data. We gratefully acknowledge research support from the Leibniz Institute for Financial Research SAFE. The views in this paper are solely those of the authors and do not necessarily reflect the views of the European Central Bank or the Central Bank of Hungary.

${ }^{\dagger}$ Leibniz Institute for Financial Research SAFE, Kiel IfW, and MNB; gyongyosi@safe-frankfurt.de.

‡European Central Bank; erzsebet-judit.rariga@ecb.europa.eu.

§assachusetts Institute of Technology, Sloan School of Management; everner@mit.edu.
} 


\section{Introduction}

Foreign currency debt often plays a central role in emerging market financial crises. From crises in Asia and Latin America in the 1990s to emerging Europe in 2008, widespread exposure to foreign currency debt combined with a sharp exchange rate depreciation weakened private-sector balance sheets, depressing consumption and investment. While its impact on firm outcomes is well-documented, less is known about how households respond to foreign currency debt revaluations. Yet household foreign currency debt has represented an important vulnerability in several financial crises, as shown in Figure $1 .^{1}$ Moreover, household balance sheets are an important transmission channel in models of international financial crises (Lorenzoni, 2014) and recent heterogeneous agent open economy macro models (de Ferra et al., 2019; Auclert et al., 2021).

In this paper, we study the effect of foreign currency household debt on householdlevel consumption during a currency crisis. Our focus is the case of Hungary around the large depreciation of the Hungarian forint starting in late 2008. Prior to the crisis, twothirds of household debt was denominated in foreign currency, primarily Swiss franc. The sharp and unexpected depreciation of the forint relative to the Swiss franc starting in October 2008 increased household debt burdens for foreign currency (FC) borrowers, but not local currency (LC) borrowers. We examine how households adjust to this balance sheet shock using detailed consumption survey data that follows households for four years and, crucially, contains information on the currency composition of housing debt.

Our empirical approach compares the consumption dynamics of foreign currency borrowers to similar local currency borrowers. Four facts support our identifying assumption of parallel trends. First, variation in households' debt currency denomination comes largely from the timing of borrowing due to changes in the availability of a government subsidy for local currency loans. As a result, FC and LC debtors are broadly similar on observable characteristics. Second, FC and LC debtors have parallel pre-trends in con-

\footnotetext{
${ }^{1}$ Appendix $\mathrm{C}$ provides additional examples of household foreign currency lending and resulting balance sheet effects during depreciations.
} 
sumption before the large depreciation. Third, our estimates are essentially unchanged when including a rich set of household controls, including contemporaneous household income. Fourth, as a placebo test, we show that non-borrowers do not reduce consumption relative to LC debtors in the crisis.

We find that households with FC debt significantly and persistently reduce consumption after the depreciation, relative to households with LC debt. The consumption response translates into a marginal propensity to consume (MPC) on nondurable consumption out of higher debt service of approximately one. This implies that nondurable consumption falls one-for-one with the increase in debt payments. When we consider total household spending including durables, we estimate a marginal propensity to spend of 1.23. This large decline in consumption estimated for foreign currency mortgage debtors is most consistent with "wealthy hand-to-mouth" behavior (Kaplan and Violante, 2014). While the increase in debt service is persistent, taking into account that debt obligations have a finite maturity, we calibrate that the permanent income hypothesis would predict a lower MPC of about 0.6.

We document a variety of margins of adjustment to the balance sheet shock that are relevant for business cycle models. We start by decomposing the fall in expenditures to understand the structure of the demand response to the foreign currency debt shock. We use detailed product-level information on expenditures to decompose the change in spending induced by the shock into reductions in spending on the intensive and extensive margins. Reduction in spending along the intensive margin accounts for 74 percent of the overall decline in spending, with the remaining 26 percent driven by the extensive margin, primarily from reduced entry into new product categories.

Focusing on the intensive margin of adjustment, 70 percent of the decline in spending is explained by a reduction in quantities purchased, and the remaining 30 percent is explained by a reduction in average prices paid. The decline in prices paid within detailed consumption categories suggests that FC debtors substitute away from more expensive to cheaper varieties following the balance sheet shock, a "flight from quality" (Burstein 
et al., 2005). The reduction in prices is consistent with nonhomothetic preferences following a shock to household balance sheets. The finding that an adverse balance sheet shock reduces the quality composition of demand has implications for measurement of consumer price inflation (Burstein et al., 2005), balance-of-payments adjustment (Bems and di Giovanni, 2016), and labor demand (Jaimovich et al., 2019).

We also examine household adjustment through labor supply. We find no effect of the shock on household market labor supply, pointing to a weak wealth effect. Our data also contain information about the sources of income, including foreign income. While overall labor supply does not increase, a small but significant subset of households adjust their labor supply toward foreign income streams by working abroad. Finally, FC debtor households increase home production, suggesting a shift in consumption from moneyintensive to time-intensive goods.

Our paper contributes to the literature on large devaluations and emerging market crises. There is a vast literature studying the consequences of firm FC debt exposure around devaluations (see, e.g., Galindo et al., 2003; Aguiar, 2005; Endrész and Harasztosi, 2014; Kim et al., 2015; Salomao and Varela, 2021; Vonnák, 2018; Niepmann and SchmidtEisenlohr, 2019). Most studies find that FC debt depresses firm investment and increases bankruptcy risk. Nevertheless, there is also evidence that firms with natural hedge select into FC debt financing and that these firms' investment is not differentially sensitive to a depreciation (Bleakley and Cowan, 2008).

In contrast, there is less evidence on the transmission of exchange rate shock through household balance sheet exposures, despite awareness that household FC exposures represented a vulnerability in crises such as Mexico in 1994 (Corsetti et al., 1999), Argentina in 2002 (IMF, 2003a), and especially several emerging European economies in the 2008 Global Financial Crisis (Ranciere et al., 2010). In Verner and Gyöngyösi (2020), we also focused on Hungary's 2008 crisis and found that sub-regional exposure to household FC debt led to a worse local recession. ${ }^{2}$ This paper complements Verner and Gyöngyösi (2020)

\footnotetext{
${ }^{2}$ Verner and Gyöngyösi (2020) also analyzed individual-level defaults and found individual and local
} 
by estimating the consumption response to the debt revaluation at the household level. To our knowledge, this is the first paper with household-level evidence on the transmission of an exchange rate shock to consumption through household balance sheets. Credit frictions and balance sheet shocks may help understand the high volatility of consumption in emerging markets and its sharp decline during many crises (Aguiar and Gopinath, 2007; Mendoza, 2010). Our estimates can therefore be used by researchers calibrating recently-developed open-economy heterogeneous models in which households have exchange rate exposure through nominal foreign currency assets and liabilities (de Ferra et al., 2019; Auclert et al., 2021). Furthermore, we provide new evidence on households' margins of adjustment. We discuss the implication of this evidence for the literature when presenting these results in section 6.

Finally, we contribute to the literature on the role of household debt in consumption decisions. Dynan (2012) studies household deleveraging in the Great Recession and shows that households with higher debt reduced their spending to a larger extent between 2007-2009. Mian et al. (2013) show that housing net worth shocks depressed consumption in the Great Recession. Di Maggio et al. (2017) find that a decline in debt burdens due to changes in interest rate has a positive effect on durable spending. Ganong and Noel (2020) study mortgage modification policies for distressed debtors in the United States and find that increased liquidity boosts consumption, whereas changes in wealth that do not increase liquidity have no effect on consumption. Our data and research design allow us to estimate the consumption response to a large and sudden increase in debt for a broad cross-section of debtors, compute the marginal propensity to consume out of higher debt service, and shed light on numerous channels of adjustment that have received little attention in previous work. Our large MPC estimates are consistent with the importance of liquidity in household spending emphasized by Ganong and Noel (2020) and the models of Kaplan and Violante (2014) and Boar et al. (2021).

The rest of the paper is structured as follows. The next section provides background spillover effects of FC debt on default. That paper, however, did not examine household-level consumption data. 
on foreign currency lending in Hungary. Sections 3 and 4 present the data and empirical framework. Section 5 presents the main results, section 6 explores the margins of adjustment, and section 7 concludes.

\section{Household foreign currency lending in Hungary}

This section provides context for Hungary's foreign currency lending boom and crisis. Credit to the retail sector in Hungary was low in the 1990s, but lending increased rapidly in 2000 after the government introduced a mortgage subsidy program. Through the program, households could borrow in local currency (LC) at nominal interest rates similar to the rates on euro-denominated mortgages and significantly below LC market lending rates. Figure 2 panel (a) shows household indebtedness in LC increased rapidly as a result.

However, by early 2004 the subsidy program was cut back, leading to an increase in interest rates on LC loans. Foreign banks responded by entering the retail lending market and competing with domestic banks by offering foreign currency (FC) denominated housing loans with lower interest rates (Banai et al., 2011). Several factors contributed to the spread of foreign currency loans including: the large interest rate differential between local and foreign currency loans and the persistent deviation from uncovered interest parity (Csajbók et al., 2010), expectations of joining the euro (Fidrmuc et al., 2013), banks seeking to match the currency composition of their assets and liabilities, and expansive foreign monetary policy (Gyöngyösi et al., 2019). By 2008, household debt increased to more than 30 percent of GDP from around 5 percent in 2000. In September 2008, 66 percent of total household debt was denominated in FC, with 97 percent of FC debt denominated in Swiss franc and the rest mostly in euro.

The exchange rate was stable before 2008, as shown in Figure 2, which further contributed to rapid lending in FC. The Hungarian National Bank maintained an \pm 15 percent exchange rate band to the euro in the 2000s, which Ilzetzki et al. (2019) classify as a de 
facto \pm 5 percent band. Meanwhile, the Swiss franc was maintained within a de facto \pm 2 percent band around the euro.

The Hungarian Central Bank abolished the exchange rate band in February 2008, and the outbreak of the crisis in September 2008 was followed by a large depreciation of the forint and appreciation of the Swiss franc. The forint depreciated by 27.5 percent against the euro and 32.3 percent against the Swiss franc between September 2008 and March 2009. By 2012, the forint depreciated by more than 50 percent against the Swiss franc compared to the pre-crisis period.

While market participants may have appreciated some risk of depreciation, a significant depreciation of the domestic currency was not the baseline expectation among households or professional forecasters. Consensus Economics forecasts show that professional forecasters anticipated a stable HUF/EUR exchange rate over one- and two-year horizons in the months before October 2008 (Figure A.1). Based on a household survey from November 2008, Pellényi and Bilek (2009) find that most FC borrowers did not expect large exchange rate movements. ${ }^{3}$

Most households had limited foreign currency income or wealth and were thus not hedged against the depreciation. ${ }^{4}$ Although Hungary joined the EU in 2004, working abroad and hence foreign currency income was negligible before the crisis. ${ }^{5}$ As Hungarian households had limited savings or income in foreign currency, the unexpected debt revaluation placed a significant burden on households through rising monthly installments. With the depreciation of the forint, default rates increased to nearly 15 percent of FC mortgage loans and 22 percent for FC home equity loans by 2012 (Figure A.2).

\footnotetext{
${ }^{3}$ Pellényi and Bilek (2009) present survey evidence that 87.2 percent of borrowers did not expect the level of exchange rate volatility that materialized in the 2008 crisis.

${ }^{4}$ Backé et al. (2007) documents using repeated cross-sectional survey data that less than 10 percent of households had foreign currency holdings between 2002 and 2006, and the median holding was around 100 EUR. Pellényi and Bilek (2009) report survey evidence that only 1.6 percent of FC borrowers had FC income or savings in 2008.

${ }^{5}$ The major destination countries for Hungarians working abroad were Austria, Germany, and the UK. Although the UK opened its labor market to the Hungarian workers in 2004, only 40,000 Hungarians migrated to the UK officially between 2004 and 2011 (Moreh, 2016). Austria and Germany only opened their labor markets completely to Hungarian citizens in 2011. Hárs (2016) uses census data and shows that less than 2 percent of Hungarian households emigrated by 2011, and emigration accelerated only after 2010.
} 
Since household debt in Hungary is full recourse and there was no provision for personal bankruptcy, the rise in default rates largely reflects the limited ability to service rising installments.

Beyond the exchange rate shock, rising interest rates on variable rate housing loans also increased debt service costs for FC debtors. Szigel (2012) quantifies the effect of the exchange rate depreciation and interest rate increases on debt service using aggregate data. He finds that exchange rate movements contributed 75 percent of the increase in debt service for FC borrowers, while interest rate increases contributed the remaining 25 percent. The crisis led to a sharp fall in aggregate consumption, which declined by 10 percent from 2008 to 2012 (Figure 2 panel (c)).

Although foreign currency loans were banned in 2010, no major policies were implemented to address increased debt burdens of existing debtors until the end of 2011. The Early Repayment Program (ERP) of 2011 allowed households to prepay their foreign currency housing debt at a preferential exchange rate. ${ }^{6}$ However, because the program required households to repay the entire outstanding debt, wealthier households were more likely to participate. Some households took out new domestic currency loans to participate in the program. Approximately 23 percent of FC debt was prepaid through the ERP. In 2012, the government also introduced the Exchange Rate Cap program, which allowed FC debtors to repay their debt at a preferential exchange rate for a grace period of five years. ${ }^{7}$ These policies were implemented after the period from 2008 to 2011 that is the central focus in our analysis.

\footnotetext{
${ }^{6}$ Gyöngyösi and Verner (2020) analyze the political economy of the crisis and provide further details on the policy response in the FC loan market.

${ }^{7}$ Participation in this program was lower than expected. In August 2012, only 16 percent of eligible borrowers had applied. MNB (2012) suggests the low participation may be explained by the fact that the program was relatively complicated.
} 


\section{Data and measurement}

\subsection{Data}

Our source for household-level consumption data is the Household Budget and Living Conditions Survey (HKÉF), administered by the Hungarian Central Statistical Office $(\mathrm{KSH})$. This is a representative survey of 8 to 10 thousand households residing in Hungary. The data has a rotating panel structure, and households are followed for four consecutive years. This provides a long within-household panel dimension relative to most consumption surveys. Our sample period is between 2005 and 2012, which provides four years of data in both the pre-depreciation period (2005-2008) and the post-depreciation period $(2009-2012) .^{8}$

The survey has two parts, a consumption diary and an interview. In the consumption diary, participants write a detailed diary tracking all expenditures for two weeks. ${ }^{9}$ The interview part of the survey takes place in the first quarter of the following year. In the interview, KSH surveys households about their major expenditures in the previous year. The interview is also used to collect detailed information on the household and each members' socioeconomic background, including includes age, education, and region (county and settlement type). ${ }^{10}$ Household members are also surveyed about their labor market status, income, and transfers in the previous year. In our analysis, we use the household weights provided by $\mathrm{KSH}$.

\subsection{Measures of consumption}

Our primary outcome variable for household consumption is real nondurable consumption expenditures. Nondurable consumption comprises strict nondurable goods, semidurable goods, and services. We exclude expenditures on durables and on home improve-

\footnotetext{
${ }^{8}$ Our sample period ends in 2012, as KSH started data collection with a completely new set of households in 2013 for the EU-SILC survey.

${ }^{9}$ An example of the diary is presented in Figure A.3.

${ }^{10}$ Information on the county and settlement type (Budapest, county capital, town, village) allows us to partition the country into 58 "regions."
} 
ment from this main measure of consumption, but we present results for these categories separately. ${ }^{11}$ We adjust consumption for family composition by dividing by the Oxford scale. ${ }^{12}$ To ensure that our results are not driven by outliers, we winsorize consumption at the top 97.5 percent. Consumption expenditures are deflated by 3-digit price indices to 2007 levels.

We also exploit the survey's detailed information on purchases by product categories. Consumption expenditures are classified at the five-digit level using the UN's Classification of Individual Consumption by Purpose (COICOP). Households also report quantities purchased for three consumption categories (food and non-alcoholic beverages, alcohol and tobacco, and clothing and footwear). These three groups account for 34.3 percent of nondurable expenditure in 2008. This allows us to calculate the average price (unit value) a household pays for the purchased items within five-digit COICOP categories. The survey also asks about home production of food and non-alcoholic beverages. We exclude home production from our main measure of nondurable consumption expenditure, but analyze it separately.

\subsection{Foreign currency debt exposure}

To classify households as FC debtors, LC debtors, and non-borrowers, we use various pieces of information on household debt. The survey includes loan-specific information on the year of origination, maturity, total amount borrowed, and the monthly payment. From 2009 onward, KSH also collects information on the currency denomination of the loan, the type of the housing loan, as well and the total debt service paid in the last year. We thus see debt currency denomination for households entering the survey before 2009

\footnotetext{
${ }^{11}$ Home improvement expenditure includes spending on materials for the maintenance and repair of the dwelling (COICOP 04.3.1) and services for the maintenance and repair of the dwelling (COICOP 04.3.2). Households undertaking major renovations report expenditures in these categories, which represents investment rather than consumption. Benmelech et al. (2017) show that home purchase is followed by an increase in home-related durable consumption and home improvements.

${ }^{12}$ The Oxford scale is given by: $1+0.7(n-1)+0.5 k$, where $n$ is the number of persons age 14 and over in the household and $k$ is the number of children under 14 . In the appendix we report results using alternative consumption equivalence scales.
} 
as long as households are present in or after 2009. As a result, we have a direct measure of debt currency denomination for all households who are in the survey in both the pre (before 2009) and post period.

To reduce measurement error in FC debt status, we determine whether households have FC or LC debt by combining the reported loan currency denomination with various other pieces of information. These are the year of origination (essentially all loans originated before 2004 are LC, while 79.3 percent of loans originated in 2004 or after are FC), the type of the loan (home equity loans are essentially all in FC as they were not subsidized), and participation in the Exchange Rate Cap or the Early Repayment Program (which only applied to FC loans). With this information, we count the number of indications of whether a household has an FC or LC loan and classify FC status based on the majority indication (for details see Appendix B). Moreover, since monthly debt payment is not reported every year, we use an annuity model to reconstruct payments and outstanding debt by combining the information on loan terms with currency-specific average interest and exchange rate data from the Hungarian National Bank (for details see Appendix B).

We validate our approach in two ways. First, we compare the estimated annuity payment with the reported payment in years when the survey asks the about latter. Appendix Figure B.9 shows that there is good fit in years after 2009. This supports our classification, as payments of FC and LC debtors diverge with the significant depreciation of the forint. Second, we compare the regional average foreign currency loan share calculated from the survey with administrative credit registry aggregates from the Hungarian National Bank in Appendix Figure B.10. The positive correlation indicates our approach correctly distinguishes between FC and LC debtor households. 


\section{Empirical framework and identification}

\subsection{Empirical specification}

We measure the effect of the foreign currency household debt shock on consumption by comparing households with FC debt to households with LC debt. We also examine non-borrowers as a placebo group. Our basic specification is the following difference-indifferences regression:

$$
\ln C_{i t}=\alpha_{i}+\delta_{t}+\beta F C_{i} \times \text { Post }_{t}+\gamma \text { NoDebt }_{i} \times \text { Post }_{t}+\Gamma X_{i t}+\varepsilon_{i t},
$$

where $\ln C_{i t}$ denotes a measure of household $i$ 's $\log$ consumption expenditure, $\alpha_{i}$ is a household fixed effect, $\delta_{t}$ is a year fixed effect, and Post $_{t}$ is an indicator variable that equals one after 2008. $F C_{i}$ and $N o D e b t_{i}$ are household-level indicator variables for households with FC debt and households without debt, respectively. The omitted group is LC borrowers. $X_{i t}$ is a set of household level control variables measured in the household's first sampling period, interacted with Post . The controls include age, gender, and education of the household head, household size, and fixed effects for 58 regional units.

\subsection{Identification}

The identifying assumption for consistent estimation of $\beta$ is that consumption would have evolved similarly for FC and LC debtors in the absence of exposure to FC debt. The threat to identification is thus time-varying household-level shocks that affect consumption and are correlated with debt currency denomination. This raises two important questions. First, why do some households enter the crisis with FC debt, while other households have LC debt? Second, what are the observable characteristics of these households and are they comparable?

Variation in households' debt currency denomination in this context is driven largely by the timing of borrowing. As discussed in Section 2, households who borrowed dur- 
ing the phase of subsidized LC loans from 2000 to early 2004 have LC loans. The large majority (79.3 percent) of households who borrowed from 2004 onward have FC debt. The importance of government policy in explaining variation in currency denomination mitigates concerns about self-selection into FC loans based on financial literacy, risk preferences, or other factors. Nevertheless, given that FC debtors and LC debtors borrowed at different points in time, they could still be meaningfully different in observables, raising concerns that their consumption would have evolved differently during the crisis in the absence of FC exposure.

Table 1 presents evidence against this concern. Specifically, the table compares the average characteristics of households in HKÉF by the currency denomination of their debt in 2008. The first three columns present the average characteristics of FC borrowers, LC borrowers, and non-borrowers, respectively. Column 4 reports the difference between FC and LC borrowers, and column 5 reports the difference between borrowers and nonborrowers. We also plot the distribution of key variables by currency denomination of debt in Figure $3 .^{13}$

Table 1 reveals that FC borrowers and LC borrowers are broadly similar along several observable dimensions. For example, there are no clear differences in household size, income, total consumption-to-income, food consumption-to-income, debt service-toincome in 2008, and liquid assets. The distributions of these variables across the two groups are also similar (Figure 3). There is some difference in educational attainment, with LC debtors being more likely to have a college education, but the distributions still have considerable overlap. ${ }^{14}$ The broad similarity between FC and LC debtors along these characteristics is consistent with the fact that the variation in exposure is driven primarily by the timing of borrowing, rather than self-selection into loan currency denomination

\footnotetext{
${ }^{13}$ Appendix Figure A.4 shows the distribution by borrower status.

${ }^{14}$ Verner and Gyöngyösi (2020) find similar patterns using two other household survey datasets with information on foreign currency debt status, the Euro Survey Project and the Tárki Household Monitor. One difference is that in these other survey datasets, FC debtors have higher education than LC debtors. Nevertheless, taken together, the evidence suggests that FC and LC borrowers do not differ substantially in terms of key observables. These findings are consistent with existing studies on household FC borrowing in emerging European countries, which find that FC and LC debtors are reasonably similar (Pellényi and Bilek, 2009; Fidrmuc et al., 2013).
} 
within a given point in time. This mitigates the concern that FC debt exposure is correlated other unobserved shocks to household consumption.

One difference between FC and LC borrowers that is worth noting is that FC borrowers are significantly less likely to live in a main city and more likely to live in a village. This is explained by the fact that smaller towns had a lower density of domestic banks, which mean that borrowers living in these areas were less likely to borrow in LC while these loans were subsidized. During the lending boom, foreign banks expanded their footprint, opening branches in previously underserved areas. This meant that households in smaller towns were more likely to take on FC denominated debt (Verner and Gyöngyösi, 2020). Given that we are interested in household level responses, in this study we control for these differences using region-by-time fixed effects.

In contrast to the differences between FC and LC debtors, the differences between borrowers and non-borrowers are more substantial. Households with debt are significantly younger, larger, have higher overall household income (but lower income per equivalence unit), and spend a lower share of income on food. Debtors are also less likely to live in the capital (Budapest) and more likely to live in other towns.

Finally, it is worth noting that with FC debt exposure rises across the income distribution, as lower income households are less likely to have debt. ${ }^{15}$ The positive covariance between income and FC debt exposure implies that the depreciation reduces inequality through FC debt exposure, as higher income households are more likely to experience adverse debt revaluations. This contrasts with previous work documenting channels through which depreciations increase inequality through differential increases in the cost of living or differential exposure to foreign assets (Cravino and Levchenko, 2017; Drenik et al., 2018).

\footnotetext{
${ }^{15}$ Figure A.5 shows more explicitly that FC debt exposure rises across the income distribution. This result also holds in a broader sample of nine economies in Emerging Europe, as show in Figure A.6a. The result is also robust to adjusting for foreign currency savings.
} 


\section{Effect of foreign currency debt on consumption}

\subsection{Main result}

Table 2 presents the results from the estimation of (1) for log household nondurable consumption as the outcome variable. We estimate the regression by using Poisson pseudomaximum likelihood (PPML) instead of OLS. This avoids the potential bias introduced by heteroskedasticity (Silva and Tenreyro, 2006). ${ }^{16}$ Standard errors are clustered at the household level. The estimation period is 2005-2012.

The first column without controls shows that FC debtors reduced consumption by 4.6 percent, relative to LC debtors, following the large depreciation of the forint. The estimate is statistically significant at the one percent level. In contrast, the effect for nonborrowers is close to zero and is not significant. In the second column of Table 2, we control for household characteristics and region fixed effects. All controls are interacted with the Post $t_{t}$ dummy. These controls absorb differential shocks affecting households that are correlated with observable characteristics such as education and preference-driven differences in the evolution of consumption. The coefficient is essentially unchanged.

A concrete threat to identification is that FC debtor households experienced different income shocks in the crisis. For example, this could happen if FC debtors were more likely to be employed in sectors severely hit by the crisis. In column 3, we also control for contemporaneous household income to account for any other income shocks that might affect consumption. Because households can adjust their labor supply in response to balance sheet shocks, this specification may over-control for income, so our preferred specification excludes this control. Nevertheless, the estimate remains statistically significant and similar in magnitude, falling modestly to -4.1 percent. ${ }^{17}$

Finally, in column 4 we control for log consumption in 2008. This effectively compares

\footnotetext{
${ }^{16}$ PPML also naturally deals with zero values in the dependent variable, which can arise for subcategories of spending. We find similar results using OLS.

${ }^{17}$ In section 6.3 , we document that a small but significant subset of households increase their foreign income share, suggesting a positive labor supply effect toward foreign income streams. However, we also show that there is no evidence that FC debtors experience a differential change in overall income (see Table 7), which further allays the concern that FC debtors are hit by differential income shocks.
} 
households that have the same pre-crisis level of consumption. While the number of observations falls by approximately half because it requires households to be in the survey in 2008 , the point estimate is again quantitatively similar. The stability of the coefficient to the inclusion of this rich set of controls supports our identifying assumption that FC debt exposure is orthogonal to time-varying shocks to consumption.

\subsection{Dynamic impact of foreign currency debt on consumption}

To understand the dynamic impact of foreign currency debt on consumption and assess the validity of the parallel trends assumption, we estimate the following dynamic difference-in-differences regression:

$$
\begin{aligned}
\ln C_{i t}= & \alpha_{i}+\delta_{t}+\sum_{k \neq 2008} \beta_{k}^{F C} F C_{i} \times \mathbb{1}_{t=k}+\sum_{k \neq 2008} \beta_{k}^{N D} N_{o D e b t_{i}} \times \mathbb{1}_{t=k} \\
& +\sum_{k \neq 2008} \Gamma_{k} X_{i t} \times \mathbb{1}_{t=k}+\varepsilon_{i t} .
\end{aligned}
$$

Figure 4 plots the sequence the coefficient estimates $\left\{\hat{\beta}^{F C}\right\}$ comparing the effect of FC debt exposure on consumption over time relative to the omitted LC group. The baseline year is 2008 based on the fact that the depreciation started in October 2008 and that the decline in aggregate consumption in annual data occurs between 2008 and 2009 (Figure 2 panel (c)).

The point estimates on $F C_{i}$ in the years preceding the crisis (2005-2007) are generally close to zero and insignificant, in line with the parallel trends assumption. There is some evidence of elevated nondurable consumption in 2006. This could be driven by new housing borrowing financing higher nondurable consumption for FC borrowers, although this estimate is not statistically significant. With the start of the crisis in late 2008, FC debtors sharply reduce consumption in 2009. The effect continuous to build throughout the crisis. The shock depressed FC debtor's consumption by 7 percent in 2012. The coefficient is significantly different from zero in all years after the onset of the depreciation. 
Figure 4 also plots the consumption response of non-borrowers, again relative to LC debtors. For non-borrowers, there is a positive but insignificant upward trend before 2008. After 2008, non-borrowers' consumption evolves similarly to LC debtors. While non-borrowers may have been differentially affected by the crisis through other channels, the absence of an effect for these households nevertheless provides a useful placebo check supporting a causal interpretation of the estimated effect of FC debt exposure on consumption.

\subsection{Marginal propensity to consume out of the debt service shock}

Theory To understand the magnitude of the consumption response to the FC debt revaluation, we estimate the marginal propensity to consume out of the increase in debt service by relating the consumption change to the increase in debt service. Before presenting the estimates, we outline the consumption response to this shock for two polar models of consumption: a permanent income (PI) consumer and a hand-to-mouth (HtM) consumer. Consider a consumer with unhedged foreign currency debt of $d$. Suppose the initial exchange rate is one and the exchange rate unexpectedly depreciates to $\mathcal{E}>1$. The change in the LC value of debt is $\mathcal{E} d-d=(\mathcal{E}-1) d \equiv \Delta d$.

Consider first the permanent income consumer. A quadratic utility permanent income consumer (Hall, 1978) smooths the increase in debt and reduces spending by $\Delta c^{P I}=$ $-r \Delta d$, where $r$ is the interest rate faced by the household. Next consider the HtM con-

sumer. In line with the data, assume debt is an annuity with payments before the depreciation given by

$$
P=d \frac{r}{1-(1+r)^{-m}} .
$$

Given that consumption of the HtM consumer responds one-for-one with the increase in 
payments, the change in consumption due to the depreciation is

$$
\Delta c^{H t M}=-\Delta d \frac{r}{1-(1+r)^{-m}}
$$

As an example, suppose that the debt is perpetual, so that $m \rightarrow \infty$. In that case, $\Delta c^{H t M}=$ $-r \Delta d$, so the PI and the HtM consumer have the same response. The infinite maturity allows the HtM consumer to smooth as if she were a PI consumer. At the other extreme, if debt must be rolled over every period $(m=1)$, then consumption declines by the full increase in debt, $\Delta c^{H t M}=-(1+r) \Delta d$.

Given these responses, it is straightforward to calculate the marginal propensity to consumer (MPC) out of increased debt service, $\triangle P$. The MPC of the HtM consumer is one, $M P C^{H t M}=1$. In contrast, the MPC of the PI consumer is given by $M P C^{P I}=$ $\Delta c^{P I} / \Delta P=1-(1+r)^{-m}$. In our sample, the average remaining maturity is $m=18$, and the average interest rate is $r=5 \%$. These values imply an MPC for the PI consumer of $M P C^{P I} \approx 0.6$. Thus, while the increase in payments is persistent, smoothing the shock for the HtM consumer, the HtM consumer still displays a larger MPC compared to the PI consumer when the contract has finite maturity.

Estimates We estimate the MPC out of the increase in annual debt service by instrumenting household debt service with FC debt exposure. In the first stage, we estimate

$$
P_{i t}=\alpha_{i}^{F S}+\delta_{t}^{F S}+\beta^{F S} F C_{i} \times \text { Post }_{t}+\Gamma^{F S} X_{i t}+\varepsilon_{i t}^{F S}
$$

where $P_{i t}$ is the "payment surprise," defined as the unanticipated level of debt service induced by the crisis. Motivated by our simple theoretical framework, the payment surprise for household $i$ in year $t$ is calculated as the difference between the actual annual debt service at the prevailing prices (exchange rates and interest rates) minus the counterfactual debt service holding fixed prices at the time of origination. Exchange rate depreciation and increases in interest rates result in larger values of the payment surprise, 
$P_{i t}$. This measure captures changes in payment induced by plausibly unexpected shocks, but it is not affected by predictable changes in debt service caused by new borrowing or pre-prepayment.

Using the predicted payment surprise, $\widehat{P}_{i t}$, in the second stage, we then estimate

$$
C_{i t}=\alpha_{i}^{S S}+\delta_{t}^{S S}+\beta^{S S} \widehat{P}_{i t}+\Gamma^{S S} X_{i t}+\varepsilon_{i t}^{S S},
$$

where $C_{i t}$ is the level of consumption in Hungarian forints. This specification measures the impact of the change in debt service induced by foreign currency exposure on household consumption. The exclusion restriction requires that the currency denomination of the loan affects consumption only through the increase in debt service.

Table 3 presents the estimates. Columns 1-3 present the reduced form effect of FC exposure on the level of consumption. FC debt exposure reduces annual nondurable consumption by 33-35 thousand HUF. Based on our preferred specification in column 2 , this corresponds to an average decline in the level of overall household nondurable consumption of 85 thousand HUF (\$652 PPP).

Table 3 columns 4-6 present the instrumental variables estimates, effectively relating the forint decline in spending to the forint increase in debt service from FC exposure. The first stage F-statistic is above 110 in all specifications, indicating that FC exposure results in a significant increase in household debt service. The estimates imply a marginal propensity to consume on nondurable consumption of 0.92 to 0.99 . Based on these estimates, spending on nondurable consumption declines approximately one-for-one with the increase in debt service in the years following the depreciation.

How does the marginal propensity to consume evolve over time? Figure 5a presents a year-by-year visualization of the MPC estimate. Specifically, we plots estimates from (2) for the level of consumption and debt service as dependent variables. We multiply the coefficient on debt service by negative one to show it on the same scale as the coefficient on consumption. We only estimate the impact on debt service following the depreciation 
in 2008, as FC exposure only induces a significant unanticipated change in debt service after the depreciation. The estimates imply that household consumption of FC debtor households declines by 50 thousand forints (\$382 PPP) per adult equivalent by 2012, relative to 2008. This corresponds to a decline in total household nondurable consumption of about 122 thousand forints (\$931 PPP).

Figure $5 \mathrm{~b}$ reports the cumulative MPC at horizons from 2009 to year $k$, calculated as follows:

$$
\operatorname{MPC}(k)=-\frac{\sum_{j=2009}^{k} \hat{\beta}_{j}^{C}}{\sum_{j=2009}^{k} \hat{\beta}_{j}^{P^{\prime}}}
$$

where $\hat{\beta}_{j}^{C}$ and $\hat{\beta}_{j}^{P}$ are the estimated effects of FC exposure on consumption and annual debt service, respectively, in year $j$ relative to 2008. Since the increase in debt service is a negative cash-flow shock, we multiply this ratio by negative one to obtain a positive MPC. The MPC in 2009 is 1.16, so nondurable consumption initially declines more than one-for-one with the increase in debt service after 2008. Once the exchange rate became unanchored, households may have expected further depreciation, leading to a larger initial consumption response. As the Swiss franc appreciated further, FC debt exposure further depressed consumption. However, the decline in consumption is smaller than the additional increase the debt service in 2011 and 2012. This coincides with the large increase in household default rates (Figure A.2), which suggests that some households conserved liquidity by defaulting. Hence, by 2012, the estimated cumulative MPC falls to 0.81 .

The point estimates of the MPC are most consistent with hand-to-mouth behavior. ${ }^{18}$ Based on our preferred estimate in Table 3 column 5, we can reject an MPC of lower than 0.42 at the 90 percent level. Therefore, strictly speaking, we cannot reject an MPC of 0.6, our calibrated MPC for a permanent income consumer, at the 10 percent level.However, the point estimates are most consistent with hand-to-mouth behavior, suggesting a role

\footnotetext{
${ }^{18}$ The initial high MPC followed by the fall in the MPC over time is consistent with consumption commitment models, e.g. Chetty and Szeidl (2007).
} 
for liquidity constraints. At a minimum, the estimates indicate that persistent shocks to cash flows lead to larger responses than transitory shocks, which are usually estimated to generate MPCs of around 0.25 (Johnson et al., 2006; Parker et al., 2013; Kaplan and Violante, 2014).

MPC heterogeneity Table A.2 explores the heterogeneity in marginal propensity to consume. The marginal propensity to consume is nearly twice as high for low-income households compared to high-income households. We also find that the MPC is larger for households with lower levels of education. These differences, however, are not statistically significant, so they should be interpreted as suggestive. There are less clear differences across high and low liquidity households and young and old households. ${ }^{19}$

\subsection{Effect on consumption sub-categories and the marginal propensity to spend on nondurables and durables}

How do FC debtor households adjust different sub-categories of consumption? Table 4 presents estimates of (1) for major expenditure categories. Panel A shows that the FC debt shock lowered spending in all categories. ${ }^{20}$ The smallest reductions are for spending on strict nondurable goods and semi-durable goods (columns 1-2). Both estimates are negative, but neither is statistically significant. The reduction in spending on services of 10 percent is larger and highly significant (column 3). The reduction in spending on durable goods of 16 percent is the most pronounced (column 4), consistent with a higher intertemporal elasticity of substitution for durable goods. ${ }^{21}$

Our baseline analysis in Table 2 considered total nondurable expenditures, which comprise the categories in columns 1-3 of Table 4. Columns 1 and 2 in Panel B of Table 4 examine total spending on nondurables and durables (the sum of the items in columns

\footnotetext{
${ }^{19}$ Households with low liquid assets are those who report in the survey that they cannot cover an unanticipated expenditure shock equal to their monthly net income from their own savings.

${ }^{20}$ The effect of FC debt on finer categories of consumption by purpose is summarized in Table A.1.

${ }^{21}$ The lower number of observation in this regression is due to fact that we use maximum likelihood for estimation and therefore households with no variation in the dependent variable (e.g. all zeros) are dropped.
} 
1 through 4 of Panel A). Column 1 shows that FC debt exposure reduced total consumption on nondurables and durables by 5.3 percent. This estimate is slightly higher than the 4.6 percent estimate on nondurables from Table 2. Using the IV setting from (4) in column 2, we estimate a marginal propensity to spend (MPS) on nondurable and durable consumption expenditures of 1.23 .

Finally, we consider housing investment, defined as spending on home maintenance and repair (COICOP 04.3.1 and 04.3.2). Column 3 in Table 4B shows that FC debtors reduce housing investment expenditures by 25 percent. This suggests that these households reduce or postpone home improvement. There are two potential explanations for this strong response. The first is that households cut back on housing investment when becoming liquidity constrained. The second is debt overhang. Highly indebted households would fear not reaping the full benefits of this investment from the increased risk that their home might be foreclosed (Melzer, 2017). Finally, in column 4 we aggregate total nondurable and durable expenditures and spending on housing investment. For this broad measure of household spending, we estimate a marginal propensity to spend of 1.30 out of the FC debt service shock.

\subsection{Difficulties making debt payments}

As additional evidence supporting the adverse balance sheet effect of FC debt exposure in the crisis, we analyze survey questions about households' difficulties making payments on their obligations. Table 5 presents the results of estimating (1) with indicator variables for whether households have difficulties making payments on items such as their mortgage and other credit. FC debtors are significantly more likely to report having difficulties making their mortgage payments, common cost payments, and payments on other credit after the onset of the crisis. For example, FC debtors see an 8.7 percentage point increase in the likelihood of reporting difficulties making their mortgage payments, compared to similar LC debtors. 


\subsection{Robustness checks}

Alternative scaling In the analysis presented thus far, we use the Oxford scale to adjust total consumption for differences in household composition. Table A.3 presents estimates of (1) and (3) for various alternative equivalence scales. In column 1, we report the effect of FC debt on total nondurable household consumption, without adjusting for household composition. We find a substantial drop in consumption, although the decline is smaller than in our baseline specification. Column 2 shows that controlling for contemporaneous household size increases the estimates for total household consumption, yielding an MPC of 0.79 . In columns 3-5, we use the "per capita," "OECD", and "square-root" equivalence scales, respectively. ${ }^{22}$ The estimates are slightly larger than our baseline when using the per-capita scale and slightly smaller when using the OECD and square-root scale. Nevertheless, the MPC estimates remain large for all scales. These results suggest that some FC debtors react to the shock by adjusting household size, perhaps to take advantage of economies of scale. We explore this further in section 6.5 below.

Propensity score matching Although FC and LC debtor households are broadly similar on observables, there are significant differences between the two groups in terms of educational attainment and income (Table 1). While the estimates are robust to controlling for these differences, we further ensure that our results are not driven by these differences by matching FC debtor households to control households using propensity score matching. We select two groups of control households: only LC debtors, or both LC debtors and non-debtors. We match households within waves and use the baseline household control variables for calculating the propensity score: age of the household head, gender of the household head, educational attainment of the household head, household size, and the location of the household.

\footnotetext{
${ }^{22}$ The per capita scale simply divides by total number of household members. The OECD scale attaches a weight of 1 to the first adult, but gives a weight of 0.5 for all the consecutive adults, while children get a weight of 0.3. The square root equivalence scale divides consumption expenditures by the square root of household size.
} 
The balance test for the two matched samples are presented in Table A.5 and Table A.6. For all observables, the differences between treatment and control groups are small and not statistically different from zero. Moreover, the Imbens and Wooldridge (2009) normalized differences are also small. Table A.4 presents the results from estimating (1) on the matched sample. For both sets of control groups, the estimates are essentially indistinguishable from the baseline estimates in Table 2.

\section{Margins of adjustment}

This section analyzes the margins of adjustment to the increase in debt burdens. We examine how households adjust to the shock by changing the quality composition of their spending, household size, labor supply and income streams, and home production.

\subsection{Quantity and quality of expenditures}

Models of household consumption with homothetic demand predict that households should adjust the quantities consumed, but not the average quality of their consumption bundles. However, models with non-homethetic demand predict that households hit by an adverse balance sheet shock may also reduce the average quality of their consumption and enter or exit certain product categories. This distinction is important for understanding the change in the composition of demand during a severe crisis, which has implications for measurement of inflation (Burstein et al., 2005), balance-of-payments adjustment (Bems and di Giovanni, 2016), and labor demand (Jaimovich et al., 2019). ${ }^{23}$

\footnotetext{
${ }^{23}$ Burstein et al. (2005) document that during Argentina's 2002 devaluation, consumers substituted toward lower quality goods. Ignoring this substitution overstates CPI inflation during large devaluations. Bems and di Giovanni (2016) use scanner data from a retailer Latvia to show that a balance of payments crisis without a devaluation but with a large decline in aggregate income led to substitution from expensive imported items to cheaper domestic alternatives. Jaimovich et al. (2019) use firm level data to show that the largest employment declines in the Great Recession in the U.S. occurred for firms producing higher quality products. They argue that this channel amplified the employment downturn in the Great Recession, as lower quality goods are less labor-intensive.
} 
Extensive vs intensive margin We begin by decomposing the change in household expenditures into the extensive margin - entry and exit from specific product categories and the intensive margin - changes in spending within product categories. Our approach follows Bems and di Giovanni (2016).

For ease of notation, we omit the household index. The change in total household expenditures between periods $t-k$ and $t, \Delta_{k} E_{t}$, can be written as

$$
\begin{aligned}
\Delta_{k} E_{t} & =E_{t}-E_{t-k}=\sum_{j \in J_{t}} e_{j t}-\sum_{j \in J_{t-k}} e_{j, t-k} \\
& =\underbrace{\sum_{j \in J_{t / t-k}} e_{j t}-\sum_{j \in J_{t / t-k}} e_{j, t-k}}_{\text {Intensive margin }}+\underbrace{\sum_{\text {Extensive margin }}^{\sum_{j \in J_{t / t-k}} e_{j, t-k}-\sum_{j \in J_{t-k}} e_{j t-k}}+\underbrace{\sum_{j \in J_{t}} e_{j t}-\sum_{j \in J_{t / t-k}} e_{j t}}_{\text {Entry }}}_{\text {Exit }},
\end{aligned}
$$

where $E_{t}$ is total expenditure in period $t, e_{j t}$ is the expenditure on item $j$ in period $t . J_{t}$ is the set of consumption categories that have positive expenditure in period $t, J_{t-k}$ is the set with positive expenditure in period $t-k$, and $J_{t / t-k}$ is the set of categories that are purchased in both periods.

The first term in (5) captures the intensive margin of adjustment. This is the change in expenditure on items purchased in both periods. The second term is the extensive margin, which covers consumption goods that are purchased in only one period. The extensive margin is the sum of the "entry" and "exit" of goods in a household's consumption basket. For example, if a household switches from buying beef to buying chicken, this translates into a decline in spending driven by exit from beef and an increase in spending driven by entry into chicken.

Price and quantity adjustment on the intensive margin The intensive margin can be decomposed into the contribution of changes in quantities purchased and average prices paid. Expenditure on consumption category $j$ may decrease between two periods for two 
reasons. First, a household may purchase a cheaper variety of the same category, but purchase the same amount. Second, the household may purchase a lower quantity of the same variety.

To do this, we calculate the Marshall-Edgeworth decomposition for the change in spending on the intensive margin, given by

$$
\begin{aligned}
\sum_{j \in J_{t / t-k}} e_{j t}-\sum_{j \in J_{t / t-k}} e_{j, t-k} & =\sum_{j \in J_{t / t-k}} p_{j t} q_{j t}-\sum_{j \in J_{t / t-k}} p_{j, t-k} q_{j, t-k} \\
& =\underbrace{\sum_{j \in J_{t / t-k}} \Delta_{k} p_{j t} \frac{q_{j t}+q_{j, t-k}}{2}}_{\text {Price change }}+\underbrace{\sum_{j \in J_{t / t-k}} \Delta_{k} q_{j t} \frac{p_{j t}+p_{j, t-k}}{2}}_{\text {Quantity change }}
\end{aligned}
$$

where $p_{j t}$ denotes the average price paid for good $j$ in period $t$, and $q_{j t}$ denotes the purchased quantity of good $j$ in period $t$. The Marshall-Edgeworth decomposition weights the price change, $\Delta_{k} p_{j t}$, by the average quantity purchased in the two periods. Similarly, it weights the quantity change, $\Delta_{k} q_{j t}$, by the average price paid in the two periods. In this decomposition, there is no composite effect. That is, there is no cross-term that depends on both the price change and the quantity change. ${ }^{24}$

Estimation and results Since these margins of adjustment are defined for the change in consumption expenditures, we estimate the impact of FC debt exposure on each margin using a regression in differences:

$$
\Delta_{k} y_{i t}=\delta_{k}+\beta_{k} F C_{i}+\gamma_{k} N_{o D e b t}+\Gamma_{k} X_{i t}+u_{i t}^{k}
$$

where $\Delta_{k} y_{i t}$ is a margin of adjustment of household $i$ between year $t-k$ and $t$. Note that taking differences sweeps away the household fixed effect. To ease the interpretation, we compute the change in the relevant margins relative to 2008. This transformation also

\footnotetext{
${ }^{24}$ Appendix B.2 discusses alternative decompositions of the intensive margin. In Table A.7, we show that these these yield similar results.
} 
makes it directly comparable to the main results. ${ }^{25}$

Table 6 presents the results of the decomposition of the intensive and extensive margins. The intensive margin contributes approximately $74 \%$ of the decline in FC debtors' spending, while the extensive margin contributes the remaining $26 \%$ of the decline. Within the extensive margin, the entirety of the effect is driven by reduced entry into new product categories. Households experiencing a debt shock were less likely to experiment by entering new product categories. In contrast, exit plays a negligible role. Table 6 also shows that the effect of FC debt on the intensive margin of consumption is driven by both a decline in quantities purchased and a decline in average prices paid. The reduction in quantities accounts for approximately 70 percent of the reduction in spending on the intensive margin, while the reduction in prices accounts for the remaining 30 percent.

The reduction in quantities is consistent with standard models in which a negative cash flow shock reduces quantities consumed. The reduction in average prices paid, however, is not consistent with standard models of homothetic preferences, such as CES preferences. Instead, it suggests that households have nonhomothetic preferences and substitute away from higher quality and toward lower quality products within tightlydefined five-digit COICOP categories. Households affected by the FC debt shock move down an upward sloping relation between household resources and average prices paid, referred to as a quality Engel curve (Bils and Klenow, 2001). ${ }^{26}$ This evidence is consistent with the "flight from quality" hypothesis (Burstein et al., 2005). ${ }^{27}$ Relative to previous work, we provide direct, within household-level evidence that balance sheet distress leads to changes in consumption baskets toward lower quality goods. ${ }^{28}$

\footnotetext{
${ }^{25}$ Specifically, we estimate (7) with the change in each margin between year $k$ and 2008 . We then average the coefficients $\hat{\beta}_{k}$ for each year in the pre-period (2005-2007) and post-period (2009-2012) and report the difference in this average.

${ }^{26}$ Bils and Klenow (2001) estimate average prices paid for durables, whereas our data allow us to measure unit prices for both nondurables and semi-durables (e.g., apparel). Jaravel (2019) and Jaimovich et al. (2020) also find that higher income households consume higher quality goods.

${ }^{27}$ Popular accounts also suggest that consumers substituted toward lower quality products during the Great Recession and the COVID-19 recession (see, e.g., The Economist, 2010; The Wall Street Journal, 2021).

${ }^{28}$ Stroebel and Vavra (2019) find that house price shocks lead to increases in retail prices, as positive shocks to wealth lead homeowners to become less price sensitive.
} 
The reduction in the quality of consumption has several important implications. First, as noted by Burstein et al. (2005), failing to adjust for changes in the quality composition of consumption leads to a downward bias in CPI inflation during crises. Second, Jaimovich et al. (2019) document that lower quality goods are less labor intensive. Hence, shifting spending toward lower quality goods amplifies the decline in labor demand following adverse shocks. Third, lower quality goods are less likely to be imported, a phenomenon known as the Alchian-Allen conjecture. Reducing quality of consumption increases import compression during debt crises, which reinforces expenditure switching from changes in relative prices (Bems and di Giovanni, 2016).

Finally, while proxying for quality with average prices is a common assumption, a related but alternative interpretation of the reduction in average prices paid is that the shock leads households to search more intensively for lower prices of the same good (e.g. Aguiar and Hurst, 2005, 2007). Research based on scanner data documents that prices for identical goods vary within markets (Kaplan and Menzio, 2015). A negative balance sheet shock could induce households to increase their product search effort and consume less leisure. Our estimates reveal that a shock to household balance sheets implies adjustment on average prices paid by affected households, but without barcode level data, we cannot disentangle these two channels.

\subsection{Wealth effect on labor supply}

Do households adjust to the shock by increasing labor supply to service higher debt payments? The impact of wealth shocks on labor supply is a longstanding question with important implications for macroeconomic and finance models. Models with separable preferences over consumption and labor predict that a negative wealth shock from an increase in debt leads households to increase labor supply (e.g., Chari et al., 2005; Devereux and Smith, 2007; Lorenzoni, 2014). Obstfeld and Rogoff (1995) show that a reduction in net foreign assets in a small open economy leads to an increase in labor and output through a wealth effect on labor supply. However, other macroeconomic models use 
non-separable preferences to remove the wealth effect on labor supply (Greenwood et al., 1988), so the wealth effect may not be empirically relevant. ${ }^{29}$ Furthermore, in models with household debt overhang, a large increase in debt leads households to reduce work effort, as higher debt service acts as a tax on labor effort (Krugman, 1988; Bernstein, 2017; Donaldson et al., 2019).

These contrasting theoretical predictions motivate a micro-level analysis of how households buffeted by a large balance sheet shock adjust their labor supply. Because we cannot directly observe work hours, we examine the effect of the FC debt shock on household income directly, following previous research (e.g., Imbens et al., 2001). In Table 7, we estimate equation (1) with household income and its components as outcome variables. Columns 1 and 2 show that FC and LC borrowers' total net income evolved similarly following the depreciation.

Table 7 columns 3 through 5 report results for various components of household income. We find no significant change in any of these components. Work-related income decreases, while social and other incomes increases. These suggest that, although FC debtor households saw minor losses in earned income relative to LC debtors, transfers compensated for this loss.

The small, negative, and insignificant effect of the FC debt shock on earned income at the household level is most consistent with models with a weak wealth effect on labor supply. It also suggests that debt overhang hang is not first order for the average FC debtor. ${ }^{30}$ Previous work by Imbens et al. (2001) and Cesarini et al. (2017) find significant but modest wealth effects on labor supply based on an analysis of lottery prize winners.

\footnotetext{
${ }^{29}$ Greenwood et al. (1988) $(\mathrm{GHH})$ preferences, $U(c-G(l))$, imply that the marginal rate of substitution between consumption $(c)$ and labor $(l)$ depends only on labor: $-\frac{U_{l}}{U_{c}}=G^{\prime}(l)$. This eliminates the wealth effect on labor supply. Non-separable preferences are commonly used in closed and open-economy macroeconomic models for this reason (e.g., Mendoza, 1991; Monacelli and Perotti, 2008; Jaimovich and Rebelo, 2009; SchmittGrohé and Uribe, 2012). For example, the model of Jaimovich and Rebelo (2009) requires a negligible wealth effect on labor supply for positive news about future productivity to generate an expansion and positive comovement between consumption, labor, and output.

${ }^{30}$ In principle, the small effects may be driven by offsetting wealth and debt overhang effects. Dissecting these channels requires a larger sample with detailed information on debt exposure and labor market outcomes. We are exploring this in ongoing work.
} 
Our evidence of a null effect may stem from the fact that we consider a negative wealth shock. It may be easier to reduce labor supply following a positive wealth shock than to increase it after a negative shock, especially in a crisis with a substantial (3 percentage point) increase in the unemployment rate. Finally, it is worth noting that the similar evolution of income across FC and LC debtors at the household level supports the assumption that our baseline consumption effects are not biased by contemporaneous adverse income shocks for FC debtors.

\subsection{Foreign currency income as a hedge against depreciation}

While households did not increase overall labor supply in response to the FC debt shock, some households may have adjusted to the crisis by seeking income from abroad. Having a household member work abroad provides access to FC income to service rising FC debt burdens. We estimate (1) with outcome variables for whether the household receives income from abroad. Although we do not directly observe the currency denomination of foreign income, the UK, Germany, and Austria were the popular destinations for Hungarian households migrating abroad (Hárs, 2016). Because the euro and British pound depreciated less against the Swiss franc than did the forint, income in these currencies would have provided some hedge against the debt revaluation.

Columns 1 and 2 in Table 8 show that FC debt exposure increased the probability of having income from abroad by 1.2 percentage points following the depreciation. While this is a modest effect in absolute terms, it is economically large compared to the negligible 0.45 percent baseline probability of having income from abroad in 2008. Results on the foreign income share in total net income are presented in columns 3 and 4 . These reveal that FC debt exposure increased the foreign income share increased by $0.5-0.6$ percentage points in the post-crisis period. This effect is also large relative to the low base rate of 0.23 percent in 2008. These results point to a significant labor supply adjustment of a small subset of households by seeking income from abroad. 


\subsection{Home production}

Another potential margin of adjustment is the substitution of money for time through home production. Standard models equate consumption with expenditures. However, a more elaborate model takes into account that households can use their time in combination with market goods to derive utility (Becker, 1965). ${ }^{31}$ Households may respond to the debt revaluation by increasing their allocation of time towards home production and decreasing the consumption of money-intensive goods. Labor supply for home production is likelier easier for households to adjust than market hours in a recession when jobs are scarce.

Based on the information in our data, we examine adjustment through home production by focusing on food production. In 2008, 31 percent of households engaged in some form of home production of food. Home production of food is an especially relevant alternative to purchasing food for rural households. ${ }^{32}$ Note that the definition of home production in HKÉF that we use is more stringent than the definition commonly used in the macroeconomics literature, which defines activities such as cooking, cleaning, and laundry as home production (e.g., Aguiar et al., 2013). ${ }^{33}$ Therefore, our results can be seen as a lower bound on overall home production activity.

Columns 1 and 2 in Table 9 present estimates of (1) with an indicator for whether a household engages in home production of food as the dependent variable. The estimate shows that, during the crisis, the probability of engaging in home production increased by 5.5 percentage points for FC debtors, relative to LC debtors. Columns 3-6 examine the substitution from money to time-intensive consumption by focusing on the value of different types of food consumption. For the value of home production, we use the im-

\footnotetext{
${ }^{31}$ Macroeconomic business cycle models find that introducing a home production sector whose output is substitutable with market consumption increases the volatility of market labor and consumption (Benhabib et al., 1991; Greenwood and Hercowitz, 1991). Home production can also help explain the "excess sensitivity" of consumption to predictable income shocks driven by changes in wages and prices (Baxter and Jermann, 1999).

${ }^{32}$ Frankenberg et al. (2003) find that households were more likely to increase home production during Indonesia's financial crisis.

${ }^{33}$ Time spent cooking or on other home production activities is not captured by the questionnaire.
} 
puted value in the survey, which assigns a market price to the reported home production. Since many households do not engage in home production or buy food services, we again estimate (1) by PPML, which accommodates this corner solution.

Table 9 column 3 shows that FC debtors' total food consumption declines in the aftermath of the crisis by a modest 2.4 percent. This estimate is not statistically significant. On the other hand, FC borrowers cut back on food service spending by 13 percent and increased home production by 20 percent. Thus, there is a large relative substitution away from expensive food away from home and toward home production. While the share of home production in total consumption is relatively small for most households, these results indicate that a subset of households attempt to smooth consumption in response to the shock by boosting home production. The increase in home production implies that the decline in expenditures overstates the decline in household consumption (Aguiar and Hurst, 2005).

\subsection{Household size and composition}

Household size and composition are choice variables that families can use to smooth the marginal utility of consumption following a large balance sheet shock. Adding an additional member, such as a parent or other extended family member, can allow households to exploit economies of scale in the presence of fixed costs or public goods. This allows the household to use additional funds to service higher debt payments and smooth consumption. Families trade off this benefit against the utility cost of decreased subfamily privacy (Frankenberg et al., 2003). ${ }^{34}$ A large, unanticipated increase in household debt may lead households to intertemporally substitute privacy over time to benefit from economies of scale of increasing household size and thereby reduce the fall in per capita consumption. ${ }^{35}$

\footnotetext{
${ }^{34}$ (Frankenberg et al., 2003) analyze households' adjustment to Indonesia's 1997 financial crisis and find that households adjust by increasing household size to benefit from economies of scale.

${ }^{35}$ Adjusting household living arrangements is rarely considered in studies of consumption smoothing. Rosenzweig and Wolpin (1993) present evidence that parents provide shared residence with their adult sons to help sons smooth consumption. Kaplan (2012) provides related evidence that young individuals use the option to move in and out of the parental home as insurance against labor market risk.
} 
To examine the extent to which households adjust the number of members in response to the increase in debt burdens, we estimate (2) with measures of household size as dependent variable. Figure A.8 reports the results. FC debtors see an 0.06 member increase in household size after the depreciation, relative to LC debtors, and a similar increase relative to non-borrowers. ${ }^{36}$ The increase in household size is modest in magnitude and not statistically significant. When distinguishing between household members by age, it shows that this increase is driven by an increase in the number of adults in the household, which is significant. The number of children evolves similarly in FC and LC debtor households. This suggests that consolidating extended family within the household to save on housing costs and exploit economies of scale allows FC debtor households adjust to the increasing debt burdens. It also highlights the importance of adjusting for household size when estimating the impact of the FC debt shock on consumption.

\section{Conclusion}

This paper studies the transmission of a large exchange rate shock to household consumption through foreign currency-denominated debt. Using household-level panel survey data around Hungary's 2008 currency crisis, we document that FC debtors reduce nondurable consumption by 7 percent relative to LC debtors following the exchange rate depreciation. This corresponds to a marginal propensity to consume on nondurable consumption of approximately one out of increased debt service. Examining a broader measure of spending that includes durables, we find an even higher MPC of 1.23. These estimates are most consistent with the importance of liquidity constraints for foreign currency debtors.

The significant pass-through of the depreciation to consumption through household balance sheets had a sizable impact on aggregate consumption. Abstracting from general

\footnotetext{
${ }^{36}$ There is a substantial negative pretrend in household size for non-borrowers, as these households are older and are more likely to have children move away from home. In contrast, LC and FC borrowers have similar trends in household size and composition in the years before the exchange rate depreciation.
} 
equilibrium effects, the foreign currency debt revaluation reduced annual nondurable consumption by 0.77 percent of GDP on average over 2009-2012. We calculate this by applying the estimated MPC from Table 3 to the increase in aggregate debt service induced by the depreciation from 2009 to 2012. Focusing on total spending including durables, the debt revaluation directly reduced annual spending by 0.97 percent of GDP over 200912. This is a large effect, especially considering that this calculation only captures the direct effect of the increase in debt service for households with FC debt. In particular, it abstracts from general equilibrium channels of the shock such as its effect on aggregate income, house prices, and the banking sector.

Households employ a variety of mechanisms to adjust to the balance sheet shock, many of which have received limited consideration in prior research. Households adjust the composition of their expenditures along both the intensive and extensive margins of product categories. On the intensive margin, FC debtors reduce expenditures both by purchasing lower quantities and lower quality goods. This is consistent with a balancesheet-induced "flight from quality." Exposed households also adjust household size and composition, likely to exploit economies of scale. We find no evidence of an increase in labor supply to increase market earnings. However, a small subset of households do respond by working abroad to access foreign currency income. Finally, there is an increase in home production, as households substitute time-intensive for money-intensive consumption. 


\section{References}

Aguiar, M. (2005). Investment, devaluation, and foreign currency exposure: The case of Mexico. Journal of Development Economics 78(1), 95-113.

Aguiar, M. and G. Gopinath (2007). Emerging market business cycles: The cycle is the trend. Journal of Political Economy 115(1), 69-102.

Aguiar, M. and E. Hurst (2005, October). Consumption versus Expenditure. Journal of Political Economy 113(5), 919-948. Publisher: The University of Chicago Press.

Aguiar, M. and E. Hurst (2007, December). Life-Cycle Prices and Production. American Economic Review 97(5), 1533-1559.

Aguiar, M., E. Hurst, and L. Karabarbounis (2013). Time use during the great recession. American Economic Review 103(5), 1664-96.

Auclert, A., M. Rognlie, M. Souchier, and L. Straub (2021). Exchange rates and monetary policy with heterogeneous agents: Sizing up the real income channel. Technical report, National Bureau of Economic Research.

Backé, P., D. Ritzberger-Grünwald, and H. Stix (2007). The Euro on the Road East: Cash, Savings and Loans. Monetary Policy E the Economy (1).

Banai, A., J. Kiraly, and M. Nagy (2011, december). The demise of the halcyon days in Hungary: foreign and local banks before and after the crisis. In B. for International Settlements (Ed.), The global crisis and financial intermediation in emerging market economies, Volume 54 of BIS Papers chapters, pp. 195-224. Bank for International Settlements.

Baxter, M. and U. J. Jermann (1999). Household production and the excess sensitivity of consumption to current income. American Economic Review 89(4), 902-920.

Becker, G. S. (1965). A Theory of the Allocation of Time. The Economic Journal 75(299), 493-517. Publisher: [Royal Economic Society, Wiley].

Beer, C., S. Ongena, and M. Peter (2010, September). Borrowing in foreign currency: Austrian households as carry traders. Journal of Banking $\mathcal{E}$ Finance 34(9), 2198-2211.

Bems, R. and J. di Giovanni (2016, December). Income-Induced Expenditure Switching. American Economic Review 106(12), 3898-3931.

Benediktsdóttir, S., G. B. Eggertsson, and E. Pórarinsson (2017). The rise, the fall, and the resurrection of iceland. Technical report, National Bureau of Economic Research.

Benhabib, J., R. Rogerson, and R. Wright (1991). Homework in macroeconomics: Household production and aggregate fluctuations. Journal of Political economy 99(6), 1166-1187.

Benmelech, E., A. Guren, and B. T. Melzer (2017, July). Making the House a Home: The Stimulative Effect of Home Purchases on Consumption and Investment. Technical Report w23570, National Bureau of Economic Research. 
Bernstein, A. (2017). Negative equity, household debt overhang, and labor supply. Journal of Finance.

Bils, M. and P. J. Klenow (2001, September). Quantifying quality growth. American Economic Review 91(4), 1006-1030.

Blanchard, O. J., M. Griffiths, and B. Gruss (2013). Boom, bust, recovery: Forensics of the latvia crisis. Brookings Papers on Economic Activity 2013(2), 325-388.

Bleakley, H. and K. Cowan (2008). Corporate dollar debt and depreciations: much ado about nothing? The Review of Economics and Statistics 90(4), 612-626.

Boar, C., D. Gorea, and V. Midrigan $(2021,10)$. Liquidity Constraints in the U.S. Housing Market. The Review of Economic Studies. rdab063.

Burstein, A., M. Eichenbaum, and S. Rebelo (2005, August). Large Devaluations and the Real Exchange Rate. Journal of Political Economy 113(4), 742-784.

Business Insider (2014). Tens of thousands of russians have loans that are now contracts of 'financial slavery'.

Cesarini, D., E. Lindqvist, M. J. Notowidigdo, and R. Östling (2017). The effect of wealth on individual and household labor supply: evidence from swedish lotteries. American Economic Review 107(12), 3917-46.

Chari, V. V., P. J. Kehoe, and E. R. McGrattan (2005). Sudden stops and output drops. American Economic Review 95(2), 381-387.

Chetty, R. and A. Szeidl (2007, May). Consumption Commitments and Risk Preferences*. The Quarterly Journal of Economics 122(2), 831-877.

Corsetti, G., P. Pesenti, and N. Roubini (1999). What caused the asian currency and financial crisis? Japan and the world economy 11(3), 305-373.

Cravino, J. and A. A. Levchenko (2017, November). The Distributional Consequences of Large Devaluations. American Economic Review 107(11), 3477-3509.

Csajbók, A., A. Hudecz, and B. Tamási (2010). Foreign currency borrowing of households in new EU member states. MNB Occasional Paper 2010/87, Magyar Nemzeti Bank (the central bank of Hungary).

de Ferra, S., K. Mitman, and F. Romei (2019). Household heterogeneity and the transmission of foreign shocks. Working Paper.

Devereux, M. B. and G. W. Smith (2007). Transfer problem dynamics: Macroeconomics of the franco-prussian war indemnity. Journal of Monetary Economics 54(8), 2375-2398.

Di Maggio, M., A. Kermani, B. J. Keys, T. Piskorski, R. Ramcharan, A. Seru, and V. Yao (2017, November). Interest Rate Pass-Through: Mortgage Rates, Household Consumption, and Voluntary Deleveraging. American Economic Review 107(11), 3550-3588. 
Donaldson, J. R., G. Piacentino, and A. Thakor (2019). Household debt overhang and unemployment. The Journal of Finance 74(3), 1473-1502.

Drenik, A., G. Pereira, and D. J. Perez (2018). Wealth redistribution after exchange rate devaluations. In AEA Papers and Proceedings, Volume 108, pp. 552-56.

Dynan, K. (2012). Is a household debt overhang holding back consumption? Brookings Papers on Economic Activity (1), 300-344.

Endrész, M. and P. Harasztosi (2014). Corporate foreign currency borrowing and investment: The case of hungary. Emerging Markets Review 21, 265-287.

Fidrmuc, J., M. Hake, and H. Stix (2013, June). Households foreign currency borrowing in Central and Eastern Europe. Journal of Banking E Finance 37(6), 1880-1897.

Fitch (2015). Azerbaijan's currency move helps buffers, but hurts banks.

Frankenberg, E., J. P. Smith, and D. Thomas (2003, March). Economic Shocks, Wealth, and Welfare. Journal of Human Resources XXXVIII(2), 280-321. Publisher: University of Wisconsin Press.

Galindo, A., U. Panizza, and F. Schiantarelli (2003). Debt composition and balance sheet effects of currency depreciation: a summary of the micro evidence. Emerging Markets Review 4(4), 330-339.

Ganong, P. and P. Noel (2020, October). Liquidity versus wealth in household debt obligations: Evidence from housing policy in the great recession. American Economic Review 110(10), 3100-3138.

Greenwood, J. and Z. Hercowitz (1991). The allocation of capital and time over the business cycle. Journal of political Economy 99(6), 1188-1214.

Greenwood, J., Z. Hercowitz, and G. W. Huffman (1988). Investment, capacity utilization, and the real business cycle. The American Economic Review, 402-417.

Gyöngyösi, G., S. Ongena, and I. Schindele (2019). The impact of monetary conditions on bank lending to households. Technical report, CEPR Discussion Paper No. DP13616.

Gyöngyösi, G. and E. Verner (2020). Financial crisis, creditor-debtor conflict, and populism. Available at SSRN 3289741.

Halac, M., S. L. Schmukler, E. Fernández-Arias, and U. Panizza (2004). Distributional effects of crises: the financial channel [with comments]. Economia 5(1), 1-67.

Hall, R. (1978). Stochastic implications of the life cycle-permanent income hypothesis: Theory and evidence. Journal of Political Economy 86(6), 971-87.

Humala, A. (2019). Corporate earnings sensitivity to fx volatility and currency exposure: evidence from peru. Working Paper. 
Hárs, A. (2016). Emigration and Immigration in Hungary after the Regime Change By International Comparison. In Z. Blaskó and K. Fazekas (Eds.), The Hungarian Labor Market 2016, pp. 39-54. Budapest: Institute of Economics, Centre for Economic and Regional Studies, Hungarian Academy of Sciences.

Ilzetzki, E., C. M. Reinhart, and K. S. Rogoff (2019, 01). Exchange Arrangements Entering the Twenty-First Century: Which Anchor will Hold?*. The Quarterly Journal of Economics 134(2), 599-646.

Imbens, G. W., D. B. Rubin, and B. I. Sacerdote (2001). Estimating the effect of unearned income on labor earnings, savings, and consumption: Evidence from a survey of lottery players. American economic review 91(4), 778-794.

Imbens, G. W. and J. M. Wooldridge (2009). Recent developments in the econometrics of program evaluation. Journal of economic literature 47(1), 5-86.

IMF (2003a). Argentina: 2002 article IV consultation. In IMF Country Report No. 03/226.

IMF (2003b). Uruguay: Staff report for the 2003 article iv consultation. Technical report, International Monetary Fund.

IMF (2015). Peru: Staff report for the 2015 article iv consultation. Technical report, International Monetary Fund.

IMF (2016). Peru: Staff report for the 2015 article iv consultation. Technical report, International Monetary Fund.

IWPR (2015). Personal debt crisis bites in azerbaijan: Loan repayments have risen by a third, leading to financial misery for borrowers.

Jaimovich, N. and S. Rebelo (2009). Can news about the future drive the business cycle? American Economic Review 99(4), 1097-1118.

Jaimovich, N., S. Rebelo, and A. Wong (2019). Trading down and the business cycle. Journal of Monetary Economics 102, 96-121.

Jaimovich, N., S. Rebelo, A. Wong, and M. B. Zhang (2020). Trading up and the skill premium. NBER Macroeconomics Annual 34(1), 285-316.

Jaravel, X. (2019). The unequal gains from product innovations: Evidence from the us retail sector. The Quarterly Journal of Economics 134(2), 715-783.

Johnson, D. S., J. A. Parker, and N. S. Souleles (2006). Household expenditure and the income tax rebates of 2001. American Economic Review 96(5), 1589-1610.

Kaplan, G. (2012). Moving back home: Insurance against labor market risk. Journal of Political Economy 120(3), 446-512.

Kaplan, G. and G. Menzio (2015). The morphology of price dispersion. International Economic Review 56(4), 1165-1206. 
Kaplan, G. and G. L. Violante (2014). A model of the consumption response to fiscal stimulus payments. Econometrica 82(4), 1199-1239.

Karaoglan, R. A. and M. Lubrano (1995). Mexico's Banks after the December 1994 Devaluation-A Chronology of the Government's Response. Nw. J. Int'l L. E Bus. 16, 24.

Kiguel, M. (2011). Argentinas 2001 economic and financial crisis: Lessons for europe. Beyond Macroeconomic Policy Coordination Discussions in the G-20, 6.

Kim, Y. J., L. L. Tesar, and J. Zhang (2015). The impact of foreign liabilities on small firms: Firm-level evidence from the korean crisis. Journal of International Economics, 209-230.

Krugman, P. (1988). Financing vs. forgiving a debt overhang. Journal of development Economics 29(3), 253-268.

Lorenzoni, G. (2014). International financial crises. Handbook of International Economics 4, 689 - 740. Handbook of International Economics.

Melzer, B. T. (2017). Mortgage debt overhang: Reduced investment by homeowners at risk of default. The Journal of Finance 72(2), 575-612.

Mendoza, E. G. (1991). Real business cycles in a small open economy. The American Economic Review, 797-818.

Mendoza, E. G. (2010, December). Sudden stops, financial crises, and leverage. American Economic Review 100(5), 1941-66.

Mian, A., K. Rao, and A. Sufi (2013). Household balance sheets, consumption, and the economic slump. The Quarterly Journal of Economics 128(4), 1687-1726.

MNB (2012, November). Financial Stability Report. Technical report.

Monacelli, T. and R. Perotti (2008). Fiscal policy, wealth effects, and markups. Technical report, National Bureau of Economic Research.

Moreh, C. (2016). Hungarian immigrants in the United Kingdom. In Z. Blaskó and K. Fazekas (Eds.), The Hungarian Labor Market 2016, pp. 69-72. Budapest: Institute of Economics, Centre for Economic and Regional Studies, Hungarian Academy of Sciences.

Müller, K. and E. Verner (2021). Credit allocation and macroeconomic fluctuations. Available at SSRN 3781981.

Musacchio, A. (2012). Mexico's financial crisis of 1994-1995.

Niepmann, F. and T. Schmidt-Eisenlohr (2019). Foreign currency loans and credit risk: Evidence from us banks.

NYT (2002). Uruguay closes all banks after currency falls by half. New York Times. 
Obstfeld, M. and K. Rogoff (1995). The intertemporal approach to the current account. Handbook of international economics 3, 1731-1799.

Parker, J. A., N. S. Souleles, D. S. Johnson, and R. McClelland (2013). Consumer spending and the economic stimulus payments of 2008. American Economic Review 103(6), 253053.

Pellényi, G. and P. Bilek (2009). Foreign currency borrowing: The case of hungary. FINESS Working Paper.

Ranciere, R., A. Tornell, and A. Vamvakidis (2010, October). Currency mismatch, systemic risk and growth in emerging europe. European Policy, 597-658.

Reuters (2021). Fx mortgages threaten poland's financial system, c.bank governor says.

Rosenberg, C. B. and M. Tirpák (2008). Determinants of foreign currency borrowing in the new member states of the eu.

Rosenzweig, M. R. and K. I. Wolpin (1993). Intergenerational support and the life-cycle incomes of young men and their parents: Human capital investments, coresidence, and intergenerational financial transfers. Journal of Labor Economics 11(1, Part 1), 84-112.

Salomao, J. and L. Varela (2021, 06). Exchange Rate Exposure and Firm Dynamics. The Review of Economic Studies. rdab032.

Schmitt-Grohé, S. and M. Uribe (2012). What's news in business cycles. Econometrica 80(6), 2733-2764.

Silva, J. M. C. S. and S. Tenreyro (2006, November). The Log of Gravity. The Review of Economics and Statistics 88(4), 641-658. Publisher: MIT Press.

Sprenger, C. and B. Urošević (2011). The housing market and housing finance in russia and its regions. Global housing markets: crises, policies, and institutions. Hoboken: John Wiley $\mathcal{E}$ Sons.

Stroebel, J. and J. Vavra (2019). House prices, local demand, and retail prices. Journal of Political Economy 127(3), 1391-1436.

Szigel, G. (2012). Less known facts about foreign currency lending to households in hungary. foreign currency lending to households in central and eastern europe. MNB Working Paper.

The Economist (2010). Basket cases: Consumer-goods companies and austerity shoppers.

The Wall Street Journal (2021). Inflation surges worldwide as covid-19 lockdowns end and supply chains can't cope.

Verner, E. and G. Gyöngyösi (2020, September). Household debt revaluation and the real economy: Evidence from a foreign currency debt crisis. American Economic Review 110(9), 2667-2702. 
Vonnák, D. (2018). Why do firms default on their foreign currency loans? The case of Hungary. Journal of International Money and Finance 86, 207-222.

Weisbrot, M. and L. Sandoval (2007). Argentina's economic recovery: Policy choices and implications. Center for Economic and Policy Research. 
Figure 1: Household and corporate foreign currency loan exposure during selected crises

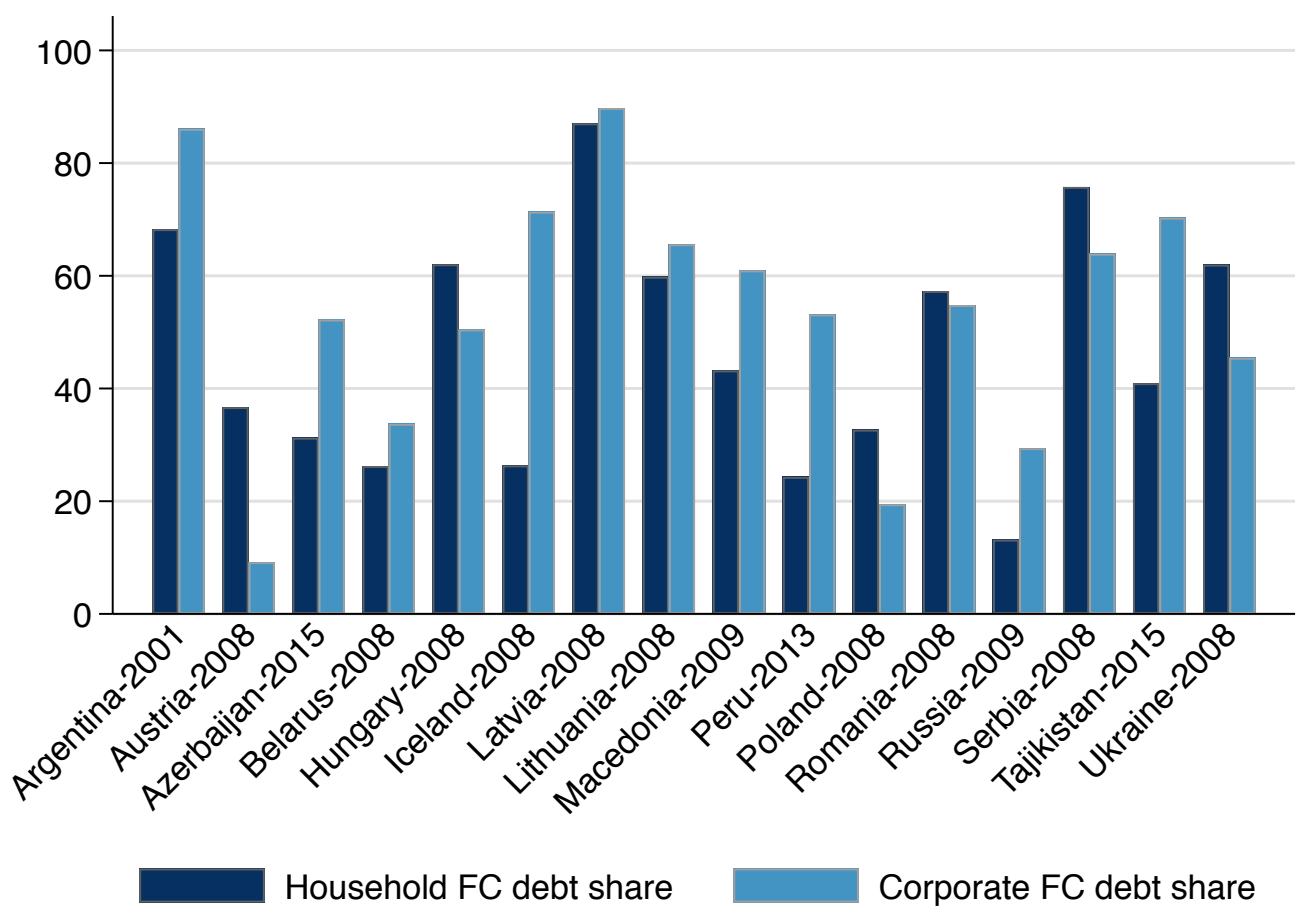

Notes: This figure plots the share of foreign currency loans in total household and non-financial corporate loans during selected episodes. The figure shows that foreign currency debt comprised an important share of household and corporate debt during these episodes. The episodes are chosen based on data availability, and most episodes involved major currency and/or banking crises. Data are collected from individual country central banks and the ECB. See Appendix C for additional details on these cases and other episodes for which data is not available. 
Figure 2: Household debt, exchange rate dynamics, and consumption around the currency crisis

(a) Household debt revaluation

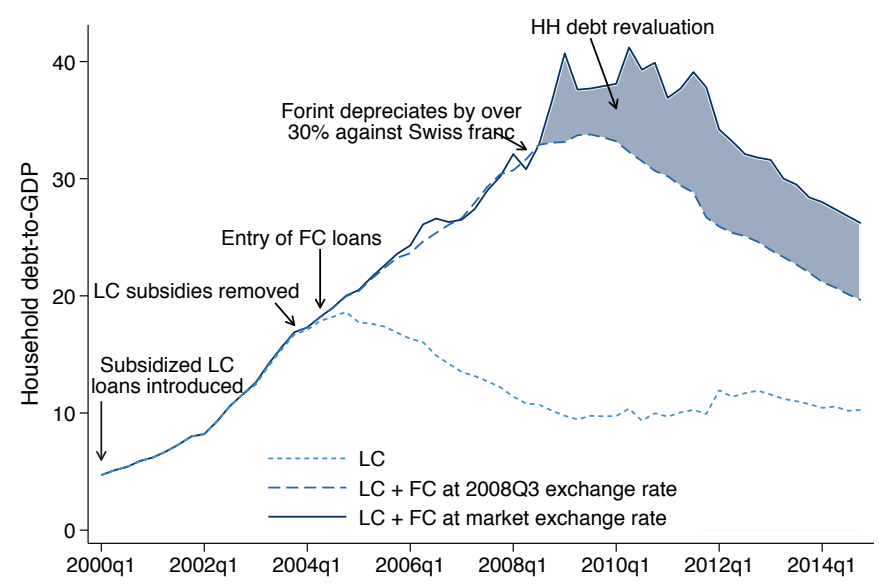

(b) Exchange rate dynamics

(c) Aggregate consumption dynamics
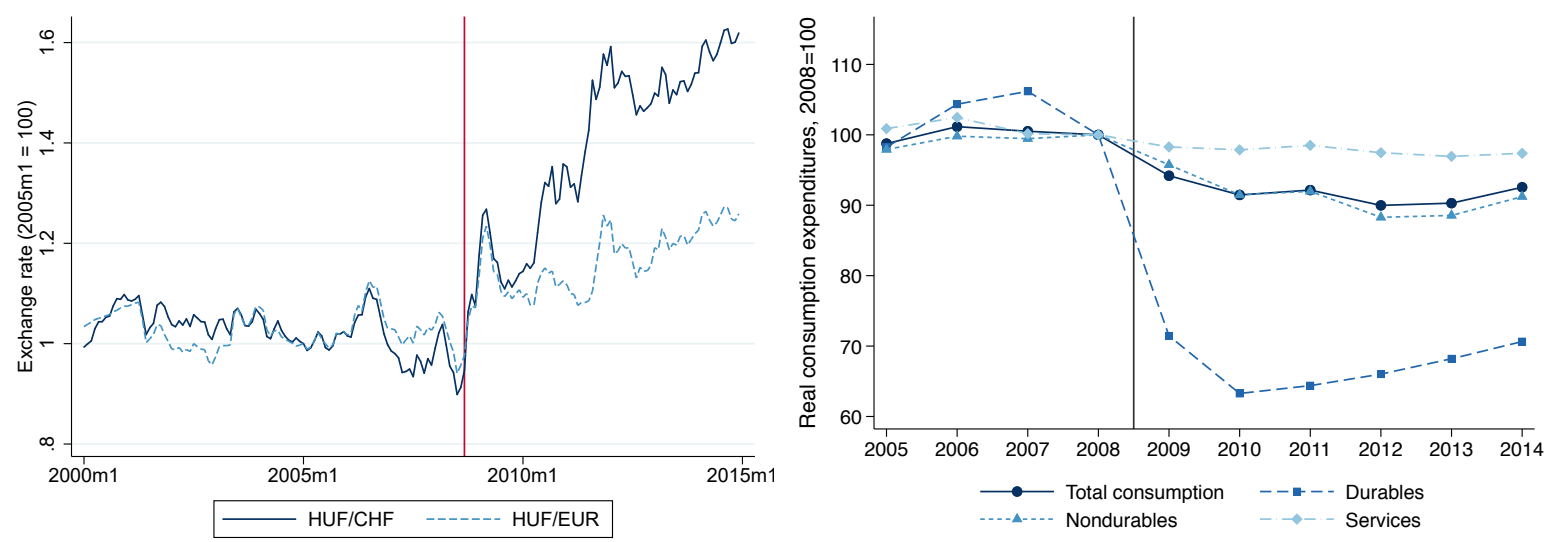

Notes: Panel (a) figure shows the evolution of household debt relative to GDP. The shaded area is the revaluation of household debt triggered by the depreciation of the Hungarian forint and appreciation of the Swiss franc. Panel (b) plots the HUF-CHF and HUF-EUR exchange rates, normalized to 100 in January 2005. An increase in the exchange rate represents a depreciation of the HUF. Panel (c) shows the dynamics of aggregate real consumption expenditures by broad consumption categories from OECD Statistics. Series are indexed to 100 in 2008. 
Figure 3: Distribution of household characteristics in 2008 by currency denomination of debt

(a) Household size

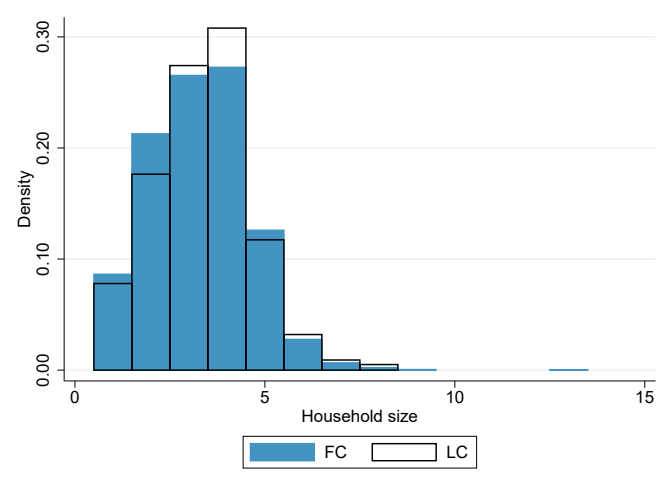

(c) Consumption to income

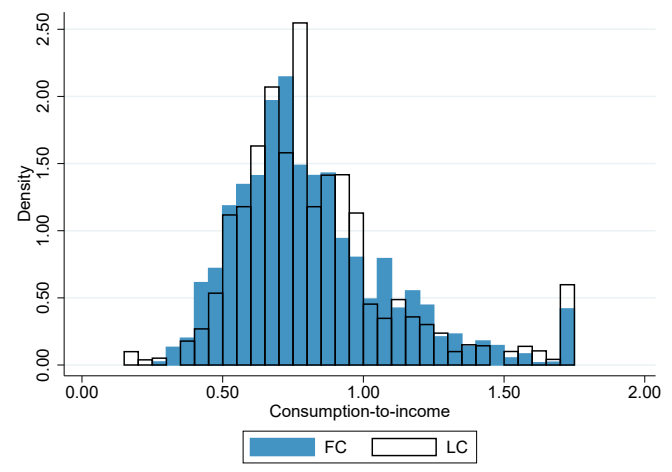

(e) Log income per capita

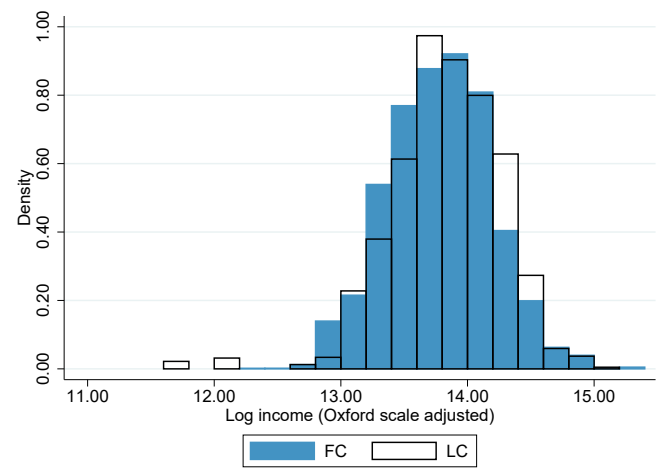

(b) Age of household head

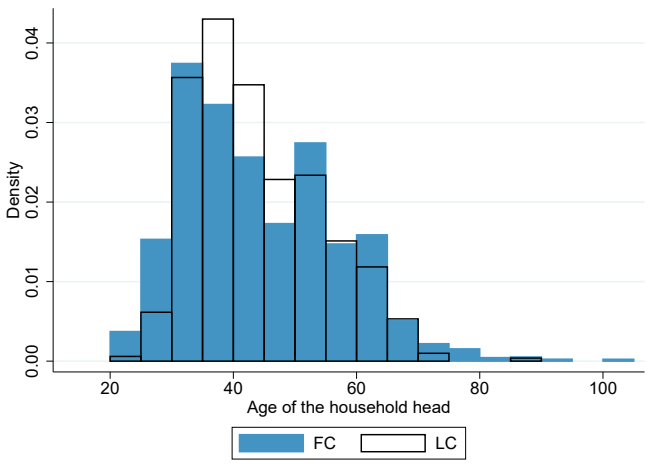

(d) Payment to income

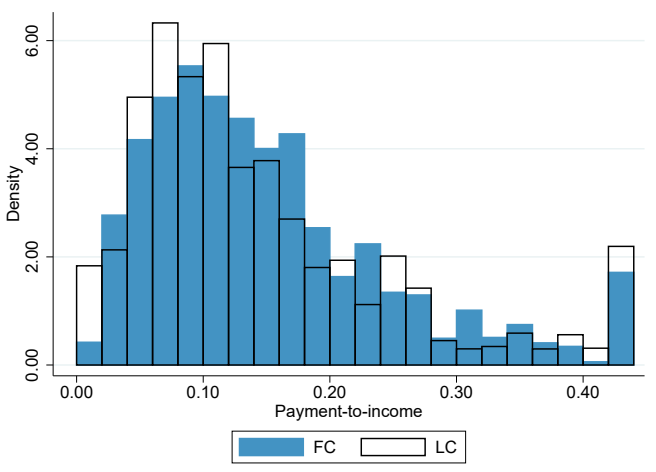

(f) Education

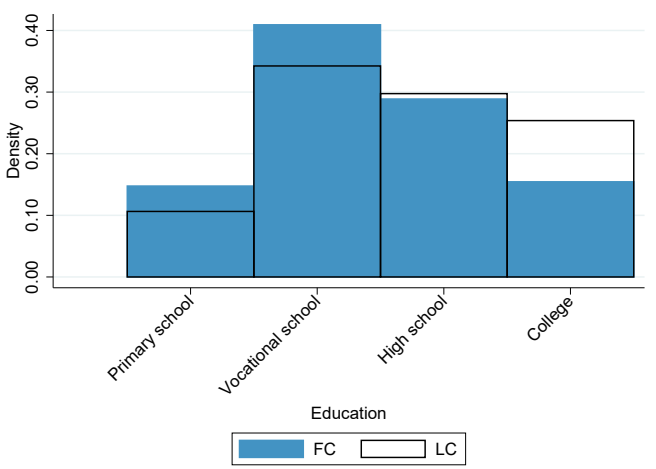

Notes: This figure shows the distribution of household characteristics by currency denomination of household debt for households in the survey in 2008. 
Figure 4: Dynamic impact of foreign currency debt exposure on consumption

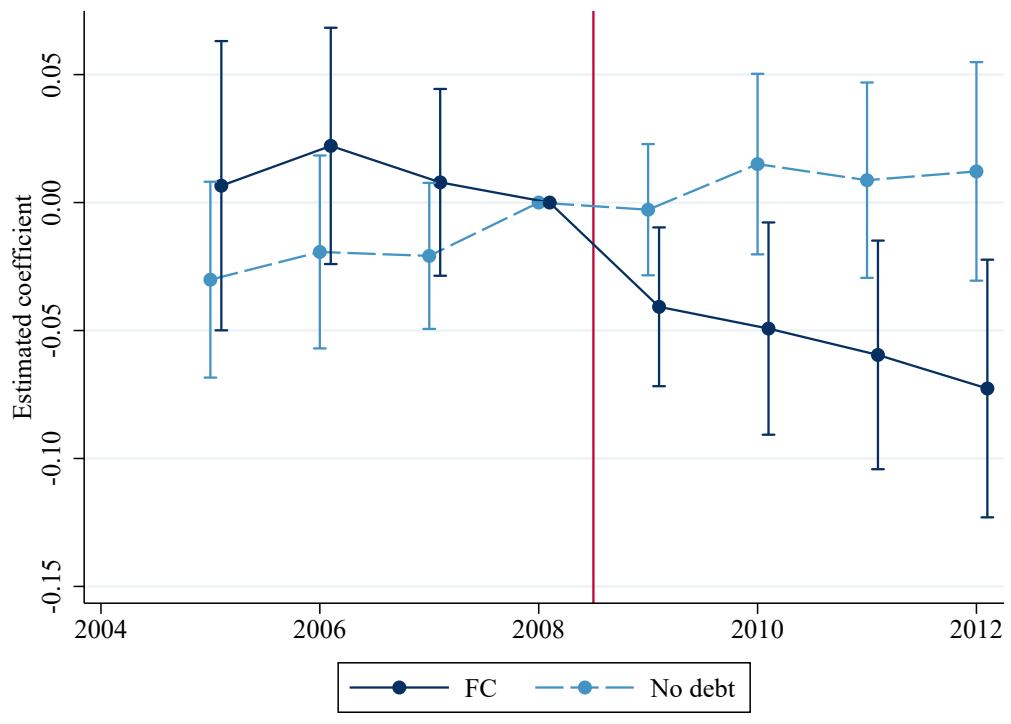

Notes: This figure plots the coefficients of interest from estimating equation (2) with log nondurable consumption as the dependent variable. The specification controls for age of the household head, gender of the household head, educational attainment of the household head, household size, and region (58 units) fixed effect. All control variables are interacted with year fixed effects. Standard errors are clustered at the household level. Errors bars represent 95 percent confidence intervals. 
Figure 5: Dynamic marginal propensity to consume

(a) Consumption and payment surprise response

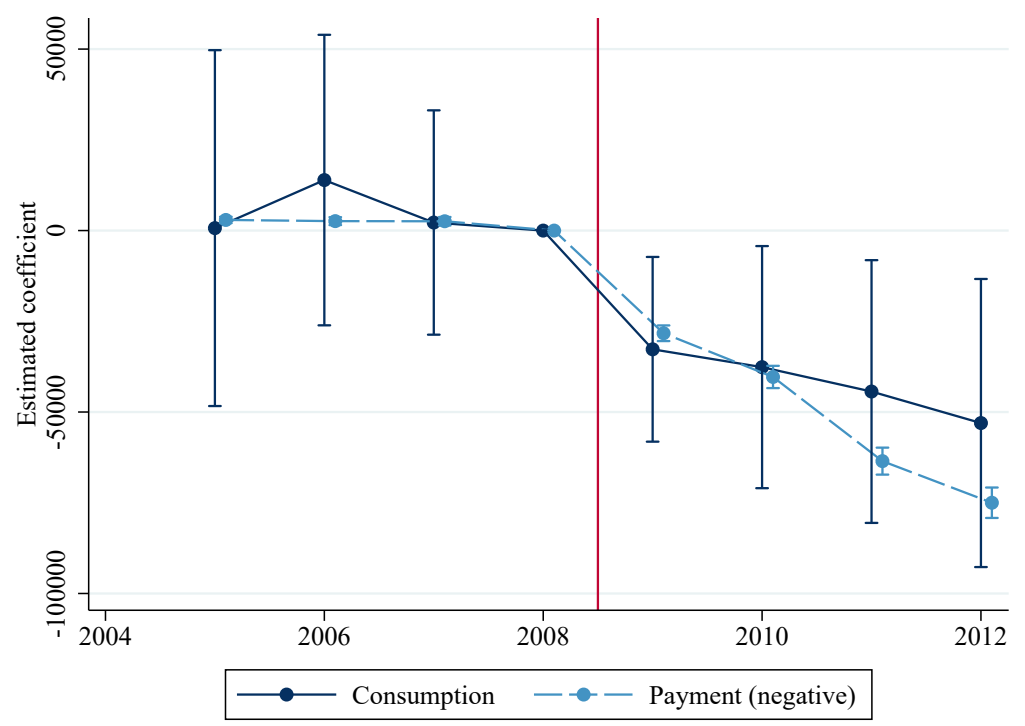

(b) Cumulative MPC

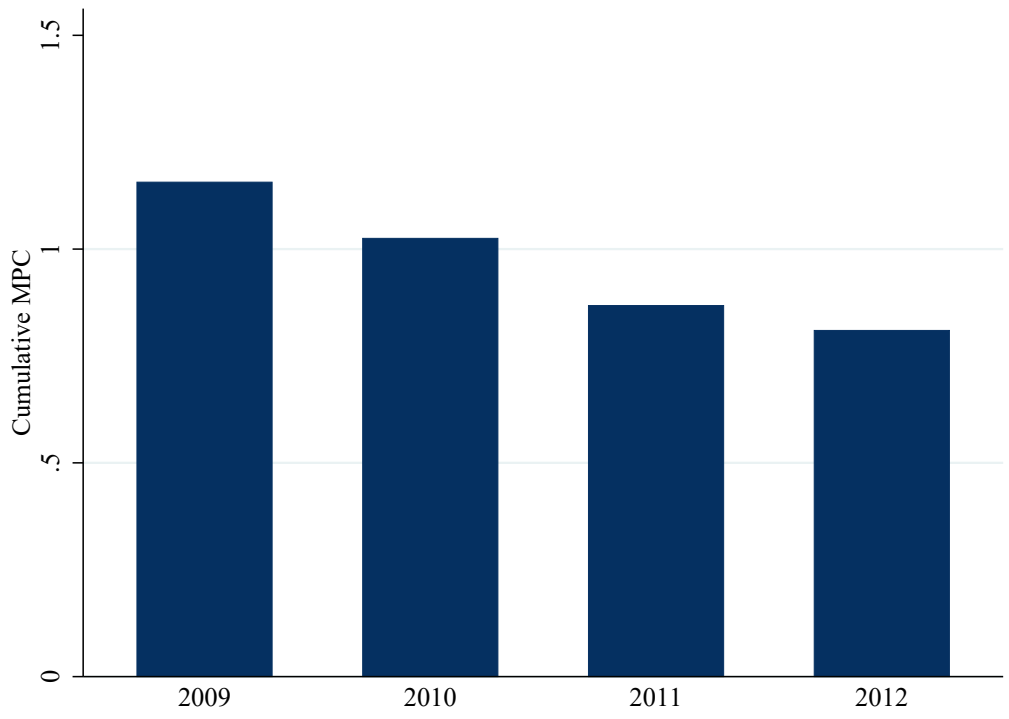

Notes: Figure (a) plots the coefficients of interest from estimating equation (2) with the level of nondurable consumption and the (negative) annual payment surprise as the dependent variable. The figure also reports the cumulative MPC relative to 2008. Controls in both specifications include age of the household head, gender of the household head, educational attainment of the household head, household size, and region (58 units) fixed effect. All control variables are interacted with year fixed effects. Standard errors are clustered at the household level. Errors bars represent 95 percent confidence intervals. Figure (b) plots the cumulative MPC defined in equation (4) using the estimates in panel (a). 
Table 1: Descriptive statistics by household loan currency denomination in 2008

\begin{tabular}{|c|c|c|c|c|c|}
\hline & $\begin{array}{c}\mathrm{FC} \\
\text { mean/sd }\end{array}$ & $\begin{array}{c}\mathrm{LC} \\
\text { mean/sd }\end{array}$ & $\begin{array}{l}\text { Non-borr. } \\
\text { mean/sd }\end{array}$ & $\begin{array}{c}\text { FC-LC } \\
\text { difference } \\
b / t\end{array}$ & $\begin{array}{l}\text { Borrower-non-borr. } \\
\text { difference } \\
\mathrm{b} / \mathrm{t}\end{array}$ \\
\hline \multirow[t]{2}{*}{ Primary school } & 0.15 & 0.11 & 0.26 & $0.04^{*}$ & $-0.13^{* *}$ \\
\hline & 0.35 & 0.31 & 0.44 & 2.07 & -11.29 \\
\hline \multirow{2}{*}{ Vocational school } & 0.41 & 0.34 & 0.30 & $0.07^{*}$ & $0.09^{* *}$ \\
\hline & 0.49 & 0.47 & 0.46 & 2.25 & 5.85 \\
\hline \multirow[t]{2}{*}{ High school } & 0.29 & 0.30 & 0.28 & -0.00 & 0.02 \\
\hline & 0.45 & 0.46 & 0.45 & -0.32 & 1.06 \\
\hline \multirow[t]{2}{*}{ College } & 0.15 & 0.25 & 0.16 & $-0.10^{* *}$ & $0.03^{*}$ \\
\hline & 0.36 & 0.44 & 0.37 & -4.18 & 2.35 \\
\hline \multirow[t]{2}{*}{ Household size } & 3.27 & 3.37 & 2.43 & -0.10 & $0.87^{* *}$ \\
\hline & 1.31 & 1.30 & 1.34 & -1.34 & 21.68 \\
\hline \multirow[t]{2}{*}{ Age } & 43.87 & 43.65 & 56.11 & 0.22 & $-12.31^{* *}$ \\
\hline & 12.50 & 10.35 & 15.27 & 0.33 & -30.88 \\
\hline \multirow[t]{2}{*}{ Female } & 0.17 & 0.14 & 0.30 & 0.03 & $-0.14^{* *}$ \\
\hline & 0.37 & 0.35 & 0.46 & 1.52 & -12.70 \\
\hline \multirow[t]{2}{*}{ Income (1000 HUF) } & 1049.15 & 1109.73 & 1062.83 & $-60.58^{*}$ & 7.07 \\
\hline & 459.40 & 455.80 & 454.21 & -2.28 & 0.50 \\
\hline \multirow[t]{2}{*}{ Consumption to income } & 0.82 & 0.84 & 0.85 & -0.02 & -0.02 \\
\hline & 0.30 & 0.33 & 0.33 & -0.90 & -1.61 \\
\hline \multirow[t]{2}{*}{ Food exp. to income } & 0.20 & 0.20 & 0.22 & 0.00 & $-0.02^{* *}$ \\
\hline & 0.10 & 0.11 & 0.11 & 0.07 & -6.16 \\
\hline \multirow[t]{2}{*}{ Payment to income } & 0.15 & 0.15 & 0.00 & 0.00 & \\
\hline & 0.09 & 0.10 & 0.00 & 0.45 & \\
\hline \multirow[t]{2}{*}{ Have liquid assets } & 0.08 & 0.10 & 0.18 & -0.02 & $-0.09^{* *}$ \\
\hline & 0.27 & 0.30 & 0.39 & -1.39 & -9.89 \\
\hline \multirow[t]{2}{*}{ Capital } & 0.16 & 0.16 & 0.20 & 0.00 & $-0.04^{* *}$ \\
\hline & 0.37 & 0.37 & 0.40 & 0.20 & -3.42 \\
\hline \multirow[t]{2}{*}{ County capital } & 0.24 & 0.29 & 0.23 & $-0.05^{+}$ & 0.02 \\
\hline & 0.43 & 0.45 & 0.42 & -1.89 & 1.41 \\
\hline \multirow[t]{2}{*}{ Town } & 0.30 & 0.30 & 0.25 & -0.00 & $0.05^{* *}$ \\
\hline & 0.46 & 0.46 & 0.43 & -0.16 & 3.57 \\
\hline \multirow[t]{2}{*}{ Village } & 0.30 & 0.25 & 0.31 & $0.05^{*}$ & $-0.03^{*}$ \\
\hline & 0.46 & 0.43 & 0.46 & 2.02 & -2.06 \\
\hline Observations & 982 & 512 & 6156 & 1494 & 7650 \\
\hline
\end{tabular}

Notes: The table presents descriptive statistics by loan currency denomination for households in the HKÉF in 2008. The first three columns show the average characteristics of foreign currency borrower households, local currency borrowers, and households without debt. The fourth column reports the difference between the average characteristics of foreign and local currency borrowers. The first seven rows report the characteristics of the household head, and the remaining rows show household-level characteristics. Consumption and income are scaled by the Oxford equivalence scale. 
Table 2: Effect of foreign currency debt shock on consumption

\begin{tabular}{lcccc}
\hline & \multicolumn{4}{c}{$\ln$ (Non-durable consumption) } \\
\cline { 2 - 5 } & $(1)$ & $(2)$ & $(3)$ & $(4)$ \\
\hline NoDebt $\times$ POST & 0.0118 & 0.0105 & 0.00984 & 0.00760 \\
& $(0.0124)$ & $(0.0128)$ & $(0.0125)$ & $(0.0127)$ \\
FC $\times$ POST & $-0.0461^{* *}$ & $-0.0461^{* *}$ & $-0.0414^{* *}$ & $-0.0446^{* *}$ \\
& $(0.0158)$ & $(0.0156)$ & $(0.0152)$ & $(0.0151)$ \\
\hline Household \& year FE & Yes & Yes & Yes & Yes \\
Household controls & & Yes & Yes & Yes \\
Contemporaneous inc. & & & Yes & Yes \\
Dep. var. 2008 & & & & Yes \\
$N$ & 59373 & 59321 & 59310 & 24951 \\
\hline
\end{tabular}

Notes: This table reports results from estimating equation (1) by Poisson pseudo-maximum likelihood (PPML). The dependent variable is log nondurable consumption, adjusted for family composition by dividing by the Oxford equivalence scale. Nondurable consumption comprises expenditures on strict nondurable goods, semi-durable goods, and services. FC and NoDebt are indicator variables for households with FC debt and without debt, respectively. POST is an indicator variable that equals one after 2008. Household controls are age of the household head, gender of the household head, educational attainment of the household head, household size, and region (58 units) fixed effects. Contemporaneous income controls for household income in each period. Dep. var. 2008 refers to specifications that control for log household nondurable consumption in 2008. All control variables, except for contemporaneous income, are interacted with the Post $t_{t}$ indicator. Standard errors are clustered at the household level. $+{ }^{*}$ and ${ }^{* *}$ denote significance at the 10 percent, 5 percent, and 1 percent level, respectively. 
Table 3: Marginal propensity to consume out of the foreign currency debt service shock

\begin{tabular}{|c|c|c|c|c|c|c|}
\hline \multirow[b]{3}{*}{$\mathrm{FC} \times \mathrm{POST}$} & \multicolumn{6}{|c|}{ Non-durable consumption } \\
\hline & \multicolumn{3}{|c|}{ Reduced form } & \multicolumn{3}{|c|}{ IV } \\
\hline & $\begin{array}{c}(1) \\
-33949.7^{* *} \\
(12724.4)\end{array}$ & $\begin{array}{c}(2) \\
-35230.5^{* *} \\
(12620.2)\end{array}$ & $\begin{array}{c}(3) \\
-32555.9^{* *} \\
(12242.5)\end{array}$ & $(4)$ & (5) & (6) \\
\hline Loan Payment surprise & & & & $\begin{array}{c}-0.957^{* *} \\
(0.359)\end{array}$ & $\begin{array}{c}-0.986^{* *} \\
(0.354)\end{array}$ & $\begin{array}{c}-0.920^{* *} \\
(0.345)\end{array}$ \\
\hline Household \& year FE & Yes & Yes & Yes & Yes & Yes & Yes \\
\hline Household controls & & Yes & Yes & & Yes & Yes \\
\hline Contemporaneous inc. & & & Yes & & & Yes \\
\hline First stage F-statistic & & & & 807.2 & 863.4 & 863.1 \\
\hline$R^{2}$ & 0.878 & 0.879 & 0.883 & & & \\
\hline$N$ & 59373 & 59321 & 59321 & 59373 & 59321 & 59321 \\
\hline
\end{tabular}

Notes: This table presents estimates of the marginal propensity to consume out of an increase in annual debt service induced by the foreign currency debt revaluation. Columns 1-3 present the reduced form estimates of the effect of FC exposure on the level (in forints) of household nondurable consumption. Columns 4-6 present the instrumental variable estimates of the MPC based on equation (3). Annual debt payment is instrumented by FC exposure interacted with Post . See Table 2 for a definition of the control variables. Standard errors are clustered at the household level.,$+{ }^{*}$ and ${ }^{* *}$ denote significance at the 10 percent, 5 percent, and 1 percent level, respectively. 
Table 4: Foreign currency debt exposure and spending on different categories of consumption

\begin{tabular}{|c|c|c|c|c|}
\hline & \multicolumn{4}{|c|}{ Panel A: By durability } \\
\hline & $\begin{array}{c}\text { Strict } \\
\text { non-durables }\end{array}$ & $\begin{array}{c}\text { Semi } \\
\text { durables }\end{array}$ & Services & Durables \\
\hline & (1) & (2) & (3) & (4) \\
\hline & PPML & PPML & PPML & PPML \\
\hline $\mathrm{FC} \times \mathrm{POST}$ & -0.0134 & -0.0568 & $-0.0981^{* *}$ & $-0.159^{+}$ \\
\hline & $(0.0173)$ & $(0.0425)$ & $(0.0236)$ & $(0.0930)$ \\
\hline Household and year FE & Yes & Yes & Yes & Yes \\
\hline Household controls & Yes & Yes & Yes & Yes \\
\hline$N$ & 59321 & 58986 & 59319 & 53539 \\
\hline
\end{tabular}

\section{Panel B: Broad spending response}

\begin{tabular}{|c|c|c|c|c|}
\hline & \multicolumn{2}{|c|}{$\begin{array}{c}\text { Total } \\
\text { consumption }\end{array}$} & \multirow{3}{*}{$\begin{array}{c}\begin{array}{c}\text { Housing } \\
\text { investment }\end{array} \\
(3) \\
\text { PPML }\end{array}$} & \multirow{3}{*}{$\begin{array}{c}\text { Total spending } \\
\text { (4) } \\
\text { IV }\end{array}$} \\
\hline & (1) & (2) & & \\
\hline & PPML & IV & & \\
\hline $\mathrm{FC} \times \mathrm{POST}$ & $\begin{array}{c}-0.0535^{* *} \\
(0.0164)\end{array}$ & & $\begin{array}{l}-0.248 \\
(0.217)\end{array}$ & \\
\hline Loan payment surprise & & $\begin{array}{c}-1.232^{* *} \\
(0.398)\end{array}$ & & $\begin{array}{c}-1.303^{* *} \\
(0.413)\end{array}$ \\
\hline Household and year FE & Yes & Yes & Yes & Yes \\
\hline Household controls & Yes & Yes & Yes & Yes \\
\hline First stage F-statistics & & 863.4 & & 863.4 \\
\hline$N$ & 59321 & 59321 & 43202 & 59321 \\
\hline
\end{tabular}

Notes: Panel A presents results from estimating (1) by PPML for various categories of consumption. The outcome variables in columns 1-3 are the components of total nondurable consumption used in Table 2. Column 4 reports the estimates for log durable spending as the dependent variable. Panel B column 1 present the PPML estimates of (1) for total consumption expenditures, defined as the sum of the measures in panel A columns 1-4. Column 2 reports the instrumental variable estimate of the MPC with total consumption expenditures as the dependent variable. Column 3 reports the PPML estimates of (1) for housing investment as the dependent variable. Column 4 presents the MPC estimate with total spending (total consumption plus housing investment) as the dependent variable. See Table 2 for a definition of the control variables. All control variables are interacted with the Post $t$ indicator. Standard errors are clustered at the household level. ,$+{ }^{*}$ and ${ }^{* *}$ denote significance at the 10 percent, 5 percent, and 1 percent level, respectively. 
Table 5: Effect of foreign currency debt exposure on payment difficulties

\begin{tabular}{|c|c|c|c|c|c|}
\hline & $\frac{\text { Mortgage }}{(1)}$ & $\frac{\text { Common cost }}{(2)}$ & $\frac{\text { Utilities }}{(3)}$ & $\frac{\text { Bank credit }}{(4)}$ & $\frac{\text { Private credit }}{(5)}$ \\
\hline $\mathrm{FC} \times \mathrm{POST}$ & $\begin{array}{l}0.0872^{* *} \\
(0.0320)\end{array}$ & $\begin{array}{l}0.0710^{*} \\
(0.0355)\end{array}$ & $\begin{array}{c}0.0155 \\
(0.0247)\end{array}$ & $\begin{array}{c}0.0527 \\
(0.0571)\end{array}$ & $\begin{array}{c}0.159^{*} \\
(0.0659)\end{array}$ \\
\hline Household and Year FE & Yes & Yes & Yes & Yes & Yes \\
\hline Household controls & Yes & Yes & Yes & Yes & Yes \\
\hline Region-Year FE & Yes & Yes & Yes & Yes & Yes \\
\hline Mean outcome in 2008 & 0.107 & 0.0891 & 0.160 & 0.0937 & 0.193 \\
\hline$R^{2}$ & 0.663 & 0.687 & 0.698 & 0.650 & 0.702 \\
\hline$N$ & 7579 & 18833 & 56904 & 7901 & 7145 \\
\hline
\end{tabular}

Notes: This table presents estimates of (1) with various measures of payment difficulties as the dependent variable. Standard errors are clustered at household level. $+{ }^{*}$ and ${ }^{* *}$ denote significance at the 10 percent, 5 percent, and 1 percent level, respectively.

Table 6: Margins of adjustment to the household foreign currency debt shock: Quality vs. quantity

\begin{tabular}{lcccccc}
\hline & Total expenditures & \multicolumn{2}{c}{ Intensive } & & \multicolumn{2}{c}{ Extensive } \\
\cline { 3 - 4 } & & Price & Quantity & & Entry & Exit \\
\hline FC $\times$ Post & $-23977.09^{* * *}$ & $-5249.1^{*}$ & $-12858.14^{*}$ & & -8879.34 & 2435.6 \\
& $(9253.20)$ & $(2617.27)$ & $(5735.29)$ & & $(5499.83)$ & $(5931)$ \\
Observations & 39689 & 39689 & 39689 & & 39689 & 39689 \\
Percent of total & - & $21.38 \%$ & $52.37 \%$ & & $36.16 \%$ & $-9.93 \%$ \\
\hline
\end{tabular}

Notes: This table reports the estimated effect of FC debt exposure on various measures of household spending based on the decomposition (5) and (6). $+{ }^{*}$ and ${ }^{* *}$ denote significance at the 10 percent, 5 percent, and 1 percent level, respectively. 
Table 7: Foreign currency debt exposure and household income

\begin{tabular}{|c|c|c|c|c|c|}
\hline & \multicolumn{2}{|c|}{ Net income } & \multicolumn{3}{|c|}{ Income components } \\
\hline & (1) & (2) & (3) & (4) & (5) \\
\hline & Total & Oxford adjusted & Wage income & Social income & Other income \\
\hline \multirow[t]{2}{*}{$\mathrm{FC} \times \mathrm{POST}$} & -0.00884 & -0.0238 & -0.0366 & 0.0134 & 0.130 \\
\hline & $(0.0174)$ & $(0.0183)$ & $(0.0283)$ & $(0.0351)$ & $(0.139)$ \\
\hline Household \& year FE & Yes & Yes & Yes & Yes & Yes \\
\hline Household controls & Yes & Yes & Yes & Yes & Yes \\
\hline$N$ & 59321 & 59321 & 52999 & 53707 & 29942 \\
\hline
\end{tabular}

Notes: This table presents estimates of (1) with various measures of household income as the dependent variable.,$+{ }^{*}$ and ${ }^{* *}$ denote significance at the 10 percent, 5 percent, and 1 percent level, respectively.

Table 8: Foreign currency debt exposure and foreign income

\begin{tabular}{lccccc}
\hline & \multicolumn{2}{c}{$\operatorname{Pr}($ Income from abroad) } & & \multicolumn{2}{c}{ Foreign income share } \\
\cline { 2 - 3 } \cline { 5 - 6 } & $(1)$ & $(2)$ & & $(3)$ & $(4)$ \\
\hline FC $\times$ POST & $0.0127^{*}$ & $0.0121^{*}$ & & $0.00603^{* *}$ & $0.00543^{* *}$ \\
& $(0.00547)$ & $(0.00562)$ & & $(0.00211)$ & $(0.00205)$ \\
\hline Household \& year FE & Yes & Yes & & Yes & Yes \\
Household controls & & Yes & & Yes \\
Average value of outcome in 2008 & 0.00456 & 0.00456 & & 0.00229 & 0.00229 \\
$N$ & 59373 & 59321 & & 59369 & 59317 \\
\hline
\end{tabular}

Notes: This table presents estimates of equation (1) with measures of working abroad as the outcome variable. Column 1-2 use an indicator variables for whether a household receives income from abroad as the dependent variable. Column 3-4 use the foreign income share in total net income as dependent variable. Standard errors are clustered at household level. $+{ }^{*}{ }^{*}$ and ${ }^{* *}$ denote significance at the 10 percent, 5 percent, and 1 percent level, respectively. 
Table 9: Foreign currency debt exposure, home production, and food consumption

\begin{tabular}{|c|c|c|c|c|c|c|}
\hline & \multicolumn{2}{|c|}{$\operatorname{Pr}($ Home production) } & \multicolumn{4}{|c|}{ Food consumption } \\
\hline & & & Total & Services & $\begin{array}{c}\text { Home } \\
\text { production }\end{array}$ & Supermarket \\
\hline & (1) & (2) & (3) & (4) & (5) & (6) \\
\hline FC $\times$ Post & $\begin{array}{l}0.0473^{+} \\
(0.0279)\end{array}$ & $\begin{array}{l}0.0552 * \\
(0.0269)\end{array}$ & $\begin{array}{l}-0.0239 \\
(0.0269)\end{array}$ & $\begin{array}{c}-0.131 \\
(0.0815)\end{array}$ & $\begin{array}{l}0.200^{+} \\
(0.119)\end{array}$ & $\begin{array}{l}-0.0169 \\
(0.0259)\end{array}$ \\
\hline Household and Year FE & Yes & Yes & Yes & Yes & Yes & Yes \\
\hline Household controls & & Yes & Yes & Yes & Yes & Yes \\
\hline Region-Year FE & & Yes & Yes & Yes & Yes & Yes \\
\hline Home production prob. in 2008 & 0.307 & 0.307 & & & & \\
\hline$R^{2}$ & 0.767 & 0.769 & & & & \\
\hline$N$ & 59373 & 59321 & 59321 & 38392 & 28899 & 59321 \\
\hline
\end{tabular}

Notes: This table presents estimates of (1) with outcome variables related to whether a household engaged in home production as the dependent variable. Standard errors are clustered at household level.,$+{ }^{*}$ and ${ }^{* *}$ denote significance at the 10 percent, 5 percent, and 1 percent level, respectively. 


\section{A Appendix figures and tables}

Figure A.1: Exchange rate expectations from Consensus Economics

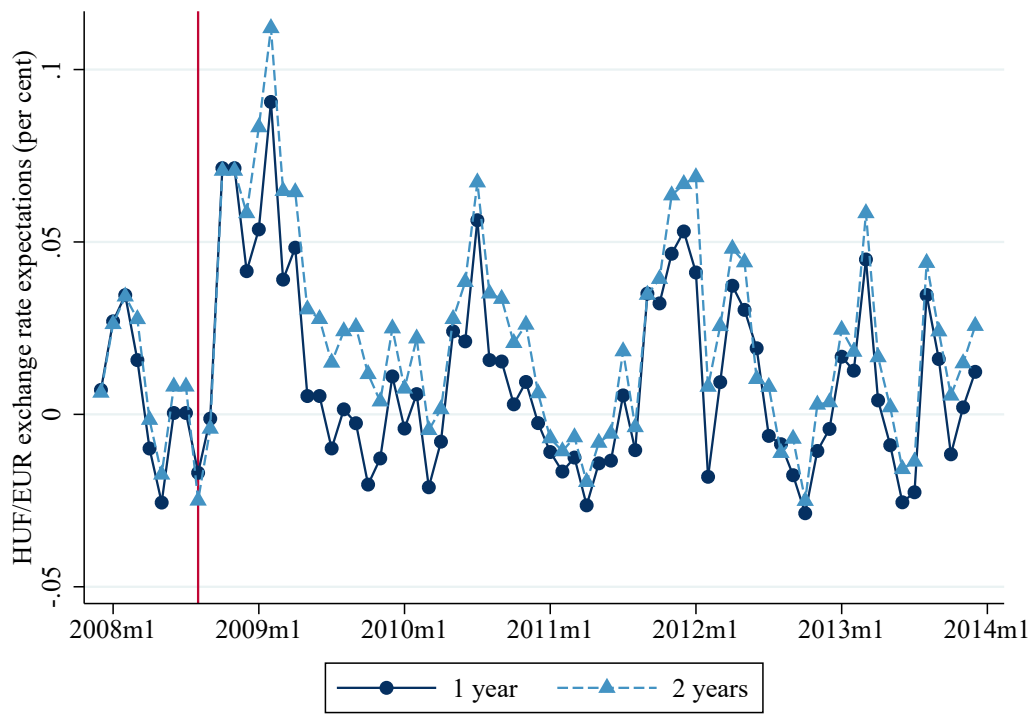

Notes: The figure plots the HUF/EUR exchange rate expectations on a 1 year and 2 years horizon from Consensus Economics forecasts. An increase in the series represents an expected depreciation of the HUF relative to the EUR. The vertical line represents September 2008. 
Figure A.2: Default rate on housing loans by currency denomination and loan type

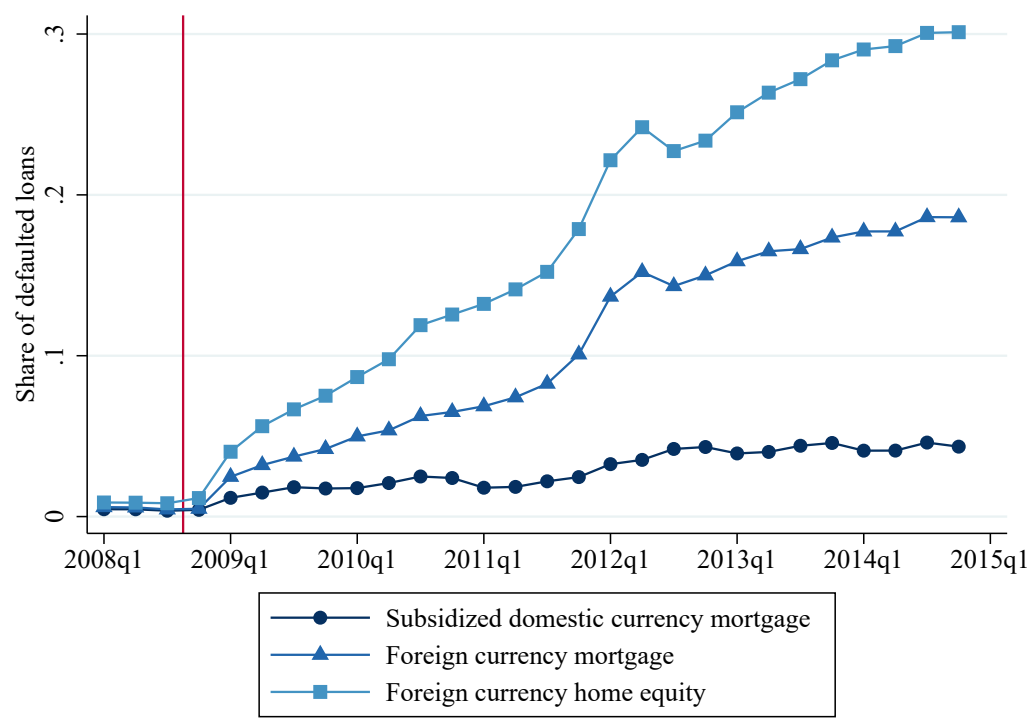

Notes: This figure shows the aggregate default rate on housing loans by currency denomination and loan type.

Figure A.3: Example of the consumption diary

\begin{tabular}{|c|c|c|c|c|c|c|c|c|c|c|}
\hline \multicolumn{11}{|c|}{ Példa a kiadások tételenként történö beírásához } \\
\hline 鹿 & Nap & $\begin{array}{l}\text { Mire mennyit költött? } \\
\text { Kóriïk }\end{array}$ & & adás & si kó & & Mennyi & & Forint & $\begin{array}{l}\text { Sze- } \\
\text { mély } \\
\text { sor- }\end{array}$ \\
\hline 01 & 1 & 2,8\%-os tartós tej, 1 liter & \begin{tabular}{|l|l|l|l|l|l|}
$\mid$ & 0 & 1
\end{tabular} & & & 10 & 1 & 0,0 & 1200 & \\
\hline 02 & 1 & 1 kg fehér kenyér & 01 & 1 & & 1 & 1 & 0,0 & 250 & \\
\hline 03 & 1 & 25 dkg baromfipárizsi & 01 & 1 & & 3 & & 25 & 1225 & \\
\hline 04 & 1 & 1 doboz cigaretta & 02 & 2 & 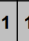 & 0 & & 1 & 150,0 & \\
\hline 05 & 2 & 1 csomag kávé, 25 dkg & 01 & 2 & & 1 & & 25 & 1530 & \\
\hline 06 & 2 & 2 korsó sör (sörözöben) & $1 / 1$ & 1 & & 8 & & & 1800 & \\
\hline 07 & 2 & munkahelyi étterem, 1 ebéd & $1 / 1$ & 1 & 2 & 1 & & & 1550 & \\
\hline 08 & 2 & 10 db tojás & \begin{tabular}{l|l} 
& 1 \\
\end{tabular} & 1 & & 0 & 10 & & 300 & \\
\hline 09 & 3 & tornacípö Petínek, 1 pár & $\begin{array}{lll}0 & 3 \\
\end{array}$ & 2 & 1 & 3 & 1 & & 1850 & 0,5 \\
\hline
\end{tabular}

Notes: This figure shows an example from the consumption diary from 2010. 
Figure A.4: Distribution of household characteristics in 2008 by borrower status

(a) Household size

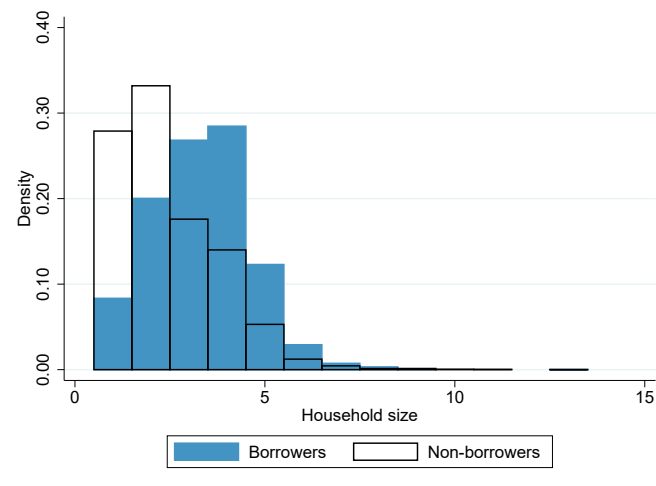

(c) Consumption to income

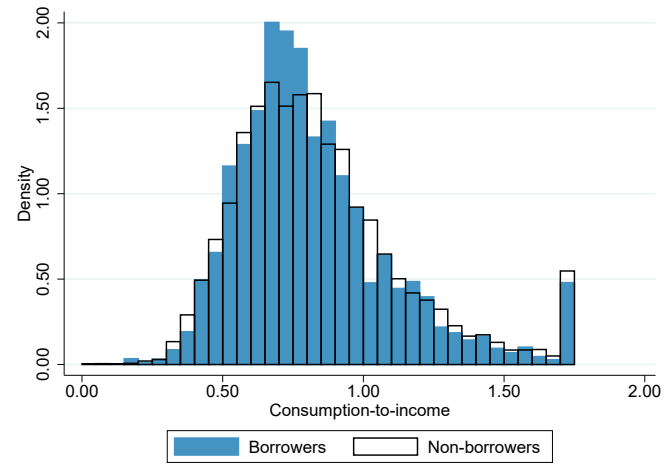

(e) Log income per capita

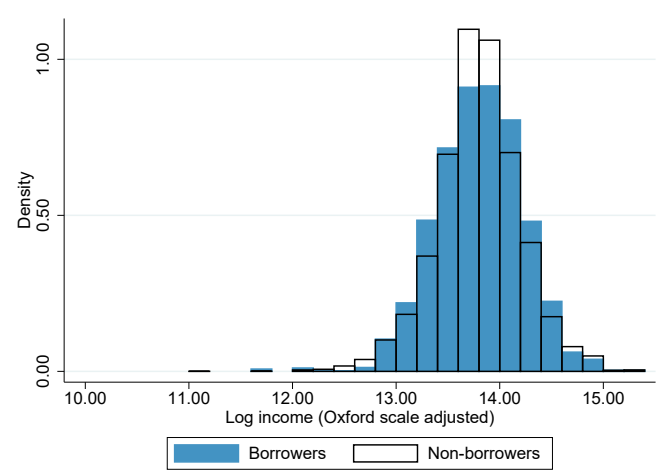

(b) Age of household head

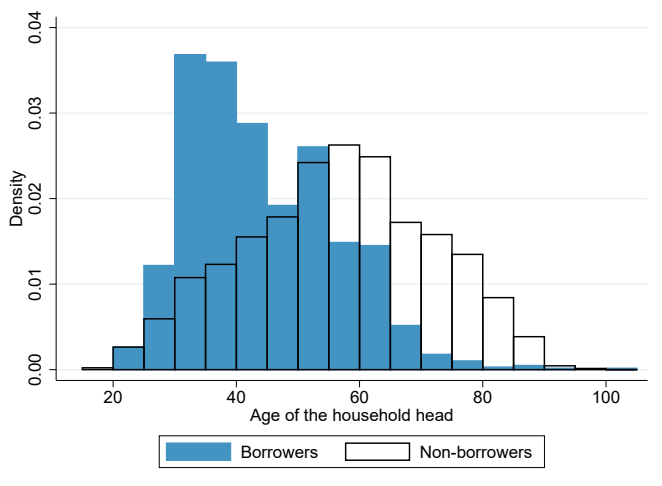

(d) Food expenditure to income

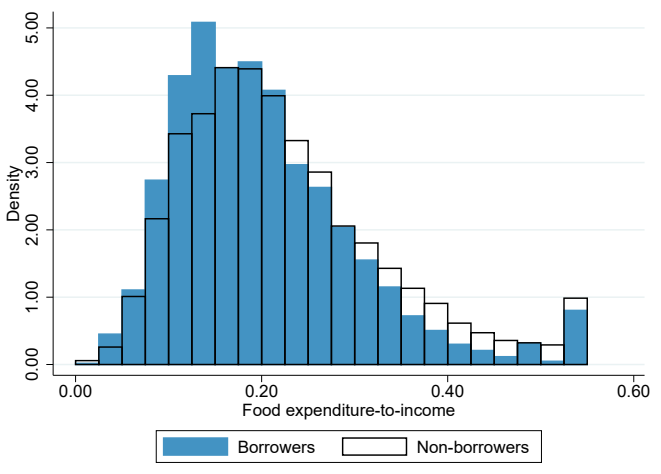

(f) Education

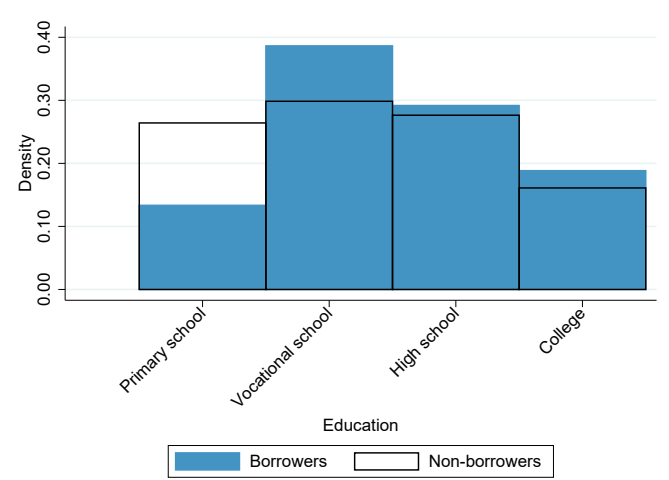

Notes: This figure shows the distribution of household characteristics for borrowers and non-borrowers. 
Figure A.5: Distributional implications: Exposure to depreciation through FC debt positions across the income distribution

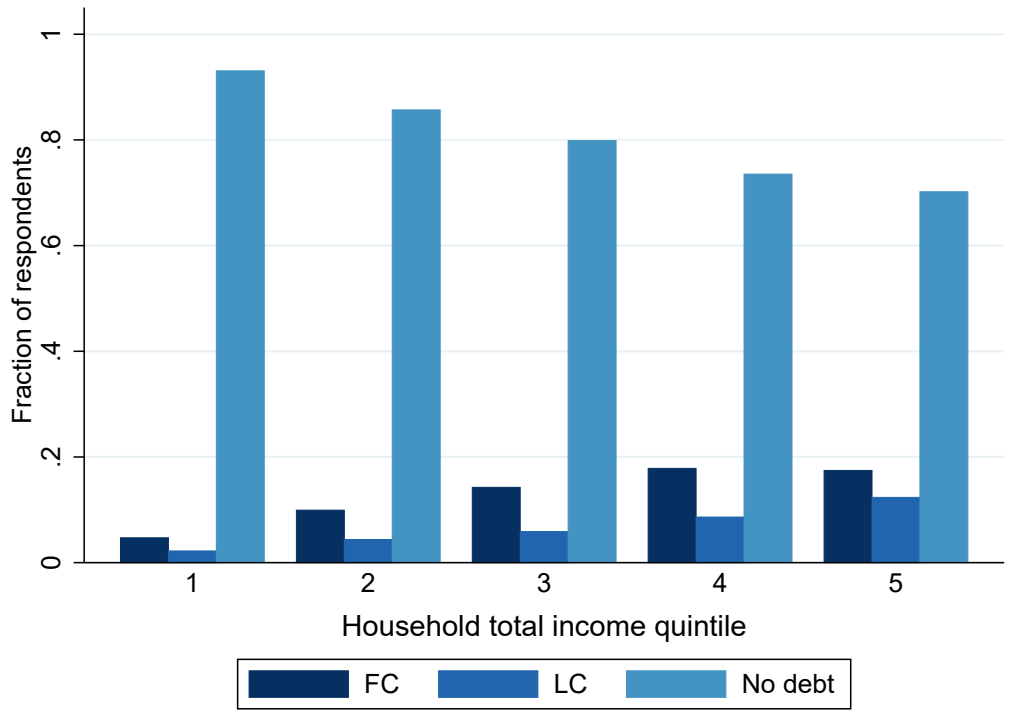

Notes: This figure plots the share of debtors by currency denomination across income quintiles in the HKÉF survey in 2008. Overall debt and FC debt exposure rise across the household income distribution. 
Figure A.6: Distributional implications of FC debt exposure: Evidence from Nine Additional Countries and Accounting for FC Savings

(a) Euro Survey Project evidence: Hungary

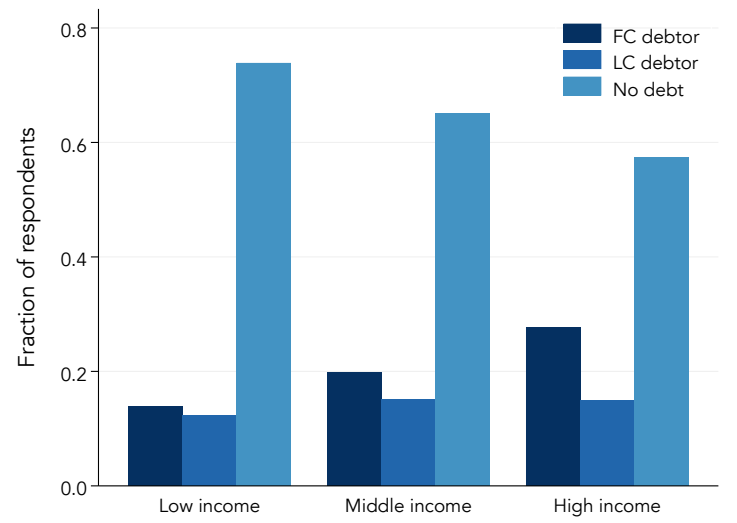

(b) Euro Survey Project evidence: Nine countries

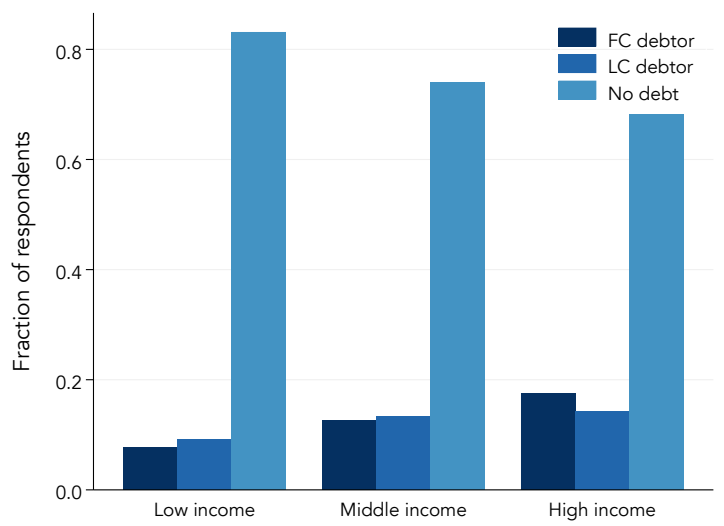

(c) FC debt exposure across income distribution for households with and without FC savings

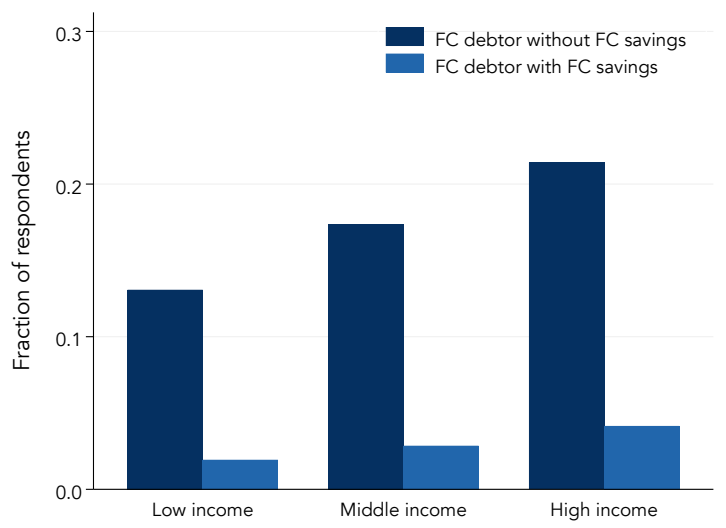

Notes: Panel (a) uses data from the Euro Survey Project and presents the fraction of respondents reporting having an FC loan, LC loan, or no debt by income terciles. The figures shows that FC debt exposure rises across income terciles.

Panel (b) in this figure reports the same statistics as panel (a) but for a sample of 9 countries in the Euro Survey Project (Albania, Bosnia and Herzegovina, Bulgaria, Croatia, Hungary, Macedonia, Poland, Romania, and Serbia). The figure shows that for FC debt exposure (and overall debt) is higher for higher levels of income in this broader sample.

Panel (c) plots the fraction of households with FC debt across the income distribution, differentiating between households that report holding FC savings and households without FC savings. The figure uses the sample of Hungarian households in the Euro Survey. The figure shows that most FC debtors do not have FC savings and therefore the rising exposure to depreciation risk across the income distribution is robust to accounting for FC savings. 
Figure A.7: Intensive and extensive margins of adjustment

(a) Intensive vs. extensive margin

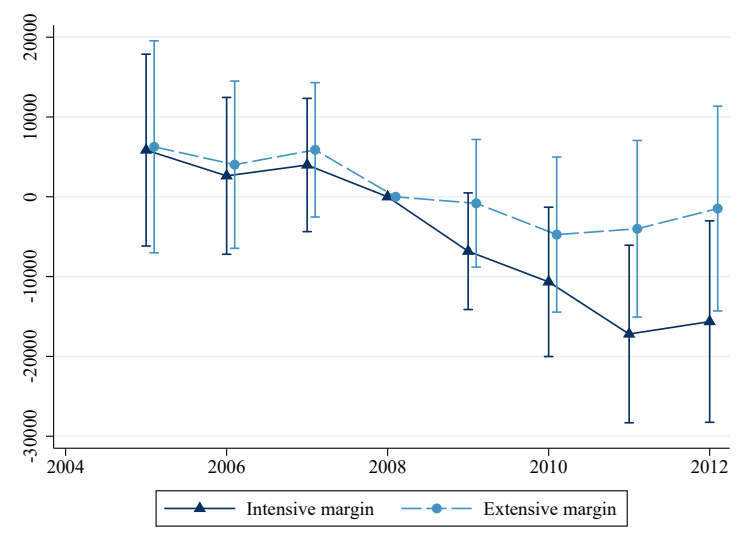

(b) Extensive margin: Entry vs exit

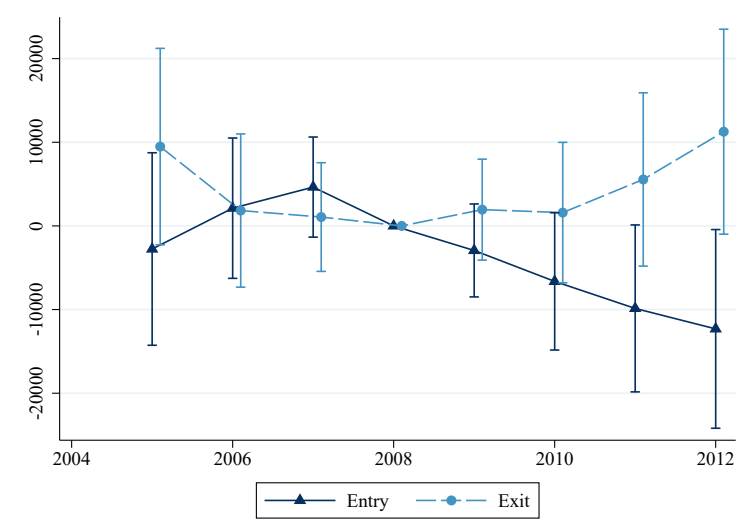

(c) Intensive margin: Price vs quantity

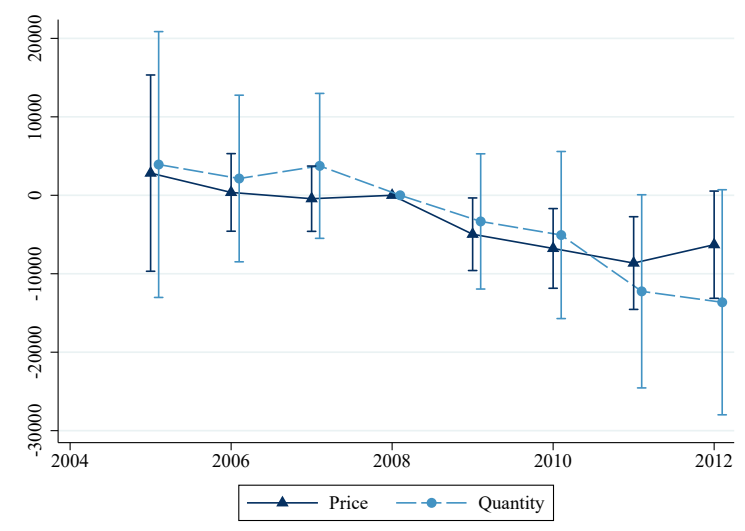

Notes: This figure plots the coefficients of interest from equation (7) using the different margins of adjustment as outcomes. Controls include age of the household head, gender of the household head, educational attainment of the household head, household size, and region (58 units) fixed effect. All control variables are interacted with year dummies. Standard errors are clustered at the household level. 
Figure A.8: Dynamic impact of foreign currency debt on measures of equivalence scales and household size

(a) Household size

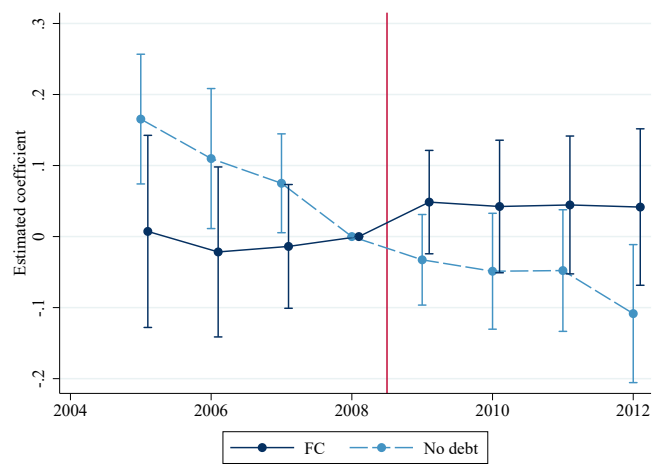

(b) Number of adults

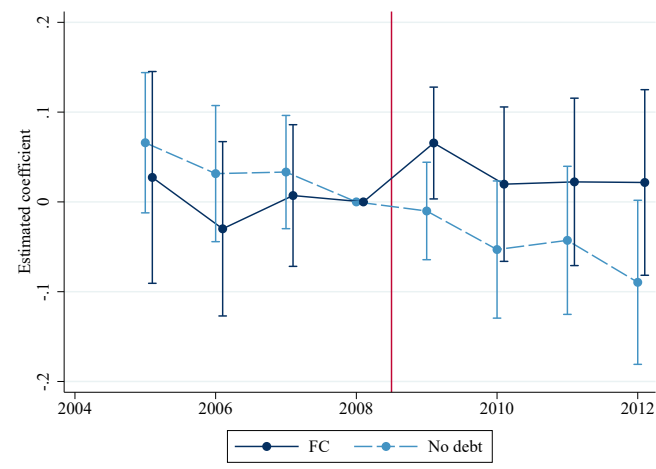

(c) Number of children below age 14

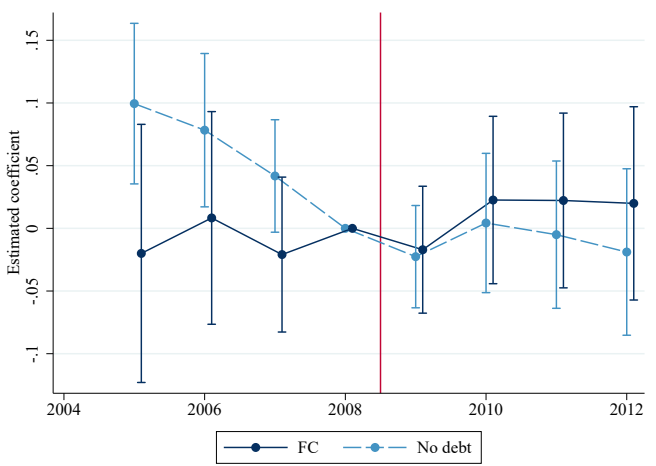

Notes: This figure plots the coefficients of interest from estimating the effect of foreign currency debt on various measures of equivalence scales and household size. The coefficients are estimating using equation (2). To avoid compositional changes driven by aging, we define an adult to be a person who was born in 1990 or earlier, while children are defined as a person to be born after 1990. 
Table A.1: Consumption by COICOP categories

\begin{tabular}{|c|c|c|c|c|c|c|c|c|c|c|c|c|}
\hline & \multicolumn{12}{|c|}{ PPML } \\
\hline & $\begin{array}{c}(1) \\
\text { Food \& } \\
\text { non-alc }\end{array}$ & $\begin{array}{c}(2) \\
\text { Alcohol } \\
\text { Tobacco }\end{array}$ & $\begin{array}{l}\text { (3) } \\
\text { Clothing } \\
\text { Footwear }\end{array}$ & $\begin{array}{c}(4) \\
\text { Housing } \\
\text { utilities }\end{array}$ & $\begin{array}{c}\text { (5) } \\
\text { Furnishing } \\
\text { HH equipment }\end{array}$ & $\begin{array}{c}\text { (6) } \\
\text { Health }\end{array}$ & $\begin{array}{c}(7) \\
\text { Transport }\end{array}$ & $\begin{array}{c}\text { (8) } \\
\text { Communication }\end{array}$ & $\begin{array}{c}\text { (9) } \\
\text { Recreation } \\
\text { Culture }\end{array}$ & $\begin{array}{c}\text { (10) } \\
\text { Education }\end{array}$ & $\begin{array}{c}(11) \\
\text { Restaurants } \\
\text { Hotels }\end{array}$ & $\begin{array}{l}(12) \\
\text { Misc }\end{array}$ \\
\hline$F C \times P O S T$ & $\begin{array}{l}-0.0183 \\
(0.0248)\end{array}$ & $\begin{array}{l}-0.0625 \\
(0.0591)\end{array}$ & $\begin{array}{c}-0.0500 \\
(0.0472)\end{array}$ & $\begin{array}{l}-0.0137 \\
(0.0529)\end{array}$ & $\begin{array}{c}-0.114 \\
(0.0701)\end{array}$ & $\begin{array}{l}-0.0765 \\
(0.0692)\end{array}$ & $\begin{array}{c}-0.0559 \\
(0.0512)\end{array}$ & $\begin{array}{c}-0.131^{* *} \\
(0.0321)\end{array}$ & $\begin{array}{c}-0.0739 \\
(0.0474)\end{array}$ & $\begin{array}{c}-0.0832 \\
(0.142)\end{array}$ & $\begin{array}{c}-0.0240 \\
(0.0832)\end{array}$ & $\begin{array}{c}-0.0840^{*} \\
(0.0411)\end{array}$ \\
\hline Household and Year FE & Yes & Yes & Yes & Yes & Yes & Yes & Yes & Yes & Yes & Yes & Yes & Yes \\
\hline Household controls & Yes & Yes & Yes & Yes & Yes & Yes & Yes & Yes & Yes & Yes & Yes & Yes \\
\hline $\begin{array}{l}\text { Region-Year FE } \\
R^{2}\end{array}$ & Yes & Yes & Yes & Yes & Yes & Yes & Yes & Yes & Yes & Yes & Yes & Yes \\
\hline$N$ & 59321 & 51821 & 58671 & 59249 & 59179 & 57214 & 48544 & 58188 & 58661 & 23216 & 37371 & 59253 \\
\hline
\end{tabular}

Notes: Standard errors are clustered at household level.,$+{ }^{*}$ and ${ }^{* *}$ denote significance at the 10 percent, 5 percent, and 1 percent level, respectively. 
Table A.2: Heterogeneity in the MPC estimates

\begin{tabular}{|c|c|c|c|c|c|c|c|c|}
\hline & \multicolumn{2}{|c|}{ Income in 2008} & \multicolumn{2}{|c|}{ Liquidity in 2008} & \multicolumn{2}{|c|}{ Education } & \multicolumn{2}{|c|}{ Age } \\
\hline & (1) & (2) & (3) & (4) & (5) & (6) & (7) & (8) \\
\hline & Low & High & Low & High & Low & High & Young & Old \\
\hline \multirow[t]{2}{*}{ Payment surprise } & $-1.428^{*}$ & -0.713 & $-0.959^{* *}$ & -0.915 & $-1.217^{*}$ & $-0.941^{+}$ & $-1.038^{* *}$ & -0.979 \\
\hline & $(0.614)$ & $(0.438)$ & $(0.371)$ & $(1.241)$ & $(0.508)$ & $(0.486)$ & $(0.364)$ & $(0.979)$ \\
\hline Household \& Year FE & Yes & Yes & Yes & Yes & Yes & Yes & Yes & Yes \\
\hline Household controls & Yes & Yes & Yes & Yes & Yes & Yes & Yes & Yes \\
\hline$N$ & 12477 & 12475 & 21007 & 3944 & 13679 & 11273 & 12567 & 12385 \\
\hline
\end{tabular}

Notes: This table presents estimates of the marginal propensity to consume by household characteristics. Columns 1 and 2 estimate (3) separately for households with above and below median income in 2008. Columns 3 and 4 split the sample into households who report having low and high liquidity. Low liquidity households are those who report that they cannot pay for an "unexpected and large" expense. Columns 5-6 and 7-8 split by above and below median education and age. Standard errors are clustered at household level.,$+{ }^{*}$ and ${ }^{* *}$ denote significance at the 10 percent, 5 percent, and 1 percent level, respectively. 
Table A.3: Foreign currency debt exposure and consumption: Alternative adjustments for household size

\begin{tabular}{|c|c|c|c|c|c|}
\hline \multicolumn{6}{|c|}{ Panel A: PPML } \\
\hline & \multicolumn{2}{|c|}{ Total } & \multirow{2}{*}{$\frac{\text { Per capita }}{(3)}$} & \multirow{2}{*}{$\frac{\text { OECD }}{(4)}$} & \multirow{2}{*}{$\frac{\text { Square Root }}{(5)}$} \\
\hline & (1) & (2) & & & \\
\hline $\mathrm{FC} \times \mathrm{POST}$ & $\begin{array}{l}-0.0325^{*} \\
(0.0148)\end{array}$ & $\begin{array}{c}-0.0374^{* *} \\
(0.0141)\end{array}$ & $\begin{array}{c}-0.0515^{* *} \\
(0.0174)\end{array}$ & $\begin{array}{c}-0.0431^{* *} \\
(0.0148)\end{array}$ & $\begin{array}{c}-0.0415^{* *} \\
(0.0143)\end{array}$ \\
\hline Household and Year FE & Yes & Yes & Yes & Yes & Yes \\
\hline Household controls & Yes & Yes & Yes & Yes & Yes \\
\hline Contemp. Household size & & Yes & & & \\
\hline$N$ & 59321 & 59321 & 59321 & 59321 & 59321 \\
\hline \multicolumn{6}{|c|}{ Panel B: Marginal propensity to consume } \\
\hline & \multicolumn{2}{|c|}{ Total } & Per capita & OECD & Square Root \\
\hline & (1) & (2) & (3) & (4) & (5) \\
\hline Payment surprise & $\begin{array}{c}-0.659^{+} \\
(0.351)\end{array}$ & $\begin{array}{l}-0.786^{*} \\
(0.335)\end{array}$ & $\begin{array}{c}-1.123^{* *} \\
(0.394)\end{array}$ & $\begin{array}{c}-0.906^{* *} \\
(0.339)\end{array}$ & $\begin{array}{c}-0.872^{* *} \\
(0.332)\end{array}$ \\
\hline Household and year FE & Yes & Yes & Yes & Yes & Yes \\
\hline Household controls & Yes & Yes & Yes & Yes & Yes \\
\hline Contemp. household size & & Yes & & & \\
\hline First stage F-statistics & 1125.5 & 1127.1 & 692.8 & 969.8 & 1034.1 \\
\hline$N$ & 59321 & 59321 & 59321 & 59321 & 59321 \\
\hline
\end{tabular}

Notes: Panel A presents estimates of (1) for alternative consumption equivalence scales. Panel B presents the corresponding MPC estimates from (3). The Oxford scale attaches weight of 1 to the first adult in the household, 0.7 to all other adults, and 0.5 to children below the age of 14 . The OECD scale similarly attaches a weight of 1 to the first adult, but gives a weight of 0.5 for all the consecutive adults, while children get a weight of 0.3 . Standard errors are clustered at household level.,$+{ }^{*}$ and ${ }^{* *}$ denote significance at the 10 percent, 5 percent, and 1 percent level, respectively. 
Table A.4: Effect of foreign currency debt on consumption: Robustness on a propensity score matched sample

\begin{tabular}{lccccc}
\hline & \multicolumn{2}{c}{ LC control } & & \multicolumn{2}{c}{ LC \& NoDebt control } \\
\cline { 2 - 3 } \cline { 6 - 6 } & $(1)$ & $(2)$ & & $(3)$ & $(4)$ \\
\hline FC $\times$ Post & $-0.0499^{*}$ & $-0.0469^{*}$ & & $-0.0513^{* *}$ & $-0.0460^{* *}$ \\
& $(0.0231)$ & $(0.0188)$ & & $(0.0170)$ & $(0.0167)$ \\
\hline Household \& Year FE & Yes & Yes & & Yes & Yes \\
Household controls & & Yes & & Yes \\
$N$ & 7125 & 7125 & & 11856 & 11856 \\
\hline
\end{tabular}

Notes: This table presents estimates of (1) on a propensity score matched sample. The dependent variable is $\log$ nondurable consumption. Households are matched within waves. The baseline household control variables for calculating the propensity score: age of the household head, gender of the household head, educational attainment of the household head, household size, and the location of the household. The caliper is set to 0.001 . Columns 1 and 2 present results using only LC debtors as controls. Columns 3 and 4 present results using both LC debtors and non-debtors as controls. Standard errors are clustered at household level. ,$+ *$ and ${ }^{* *}$ denote significance at the 10 percent, 5 percent, and 1 percent level, respectively. 
Table A.5: Balancedness for propensity score matched sample, LC debtors as controls

\begin{tabular}{lccccc}
\hline & Treatment & Control & $\begin{array}{c}\text { Treatment- } \\
\text { Control } \\
\text { Diff. }\end{array}$ & t-statistic & $\begin{array}{c}\text { Normalized } \\
\text { Diff. }\end{array}$ \\
\hline Primary school & 0.12 & 0.11 & 0.01 & 0.30 & 0.02 \\
Vocational school & 0.46 & 0.46 & -0.00 & -0.02 & -0.00 \\
High school & 0.30 & 0.32 & -0.02 & -0.46 & -0.03 \\
College & 0.13 & 0.11 & 0.01 & 0.54 & 0.03 \\
Household size & 3.24 & 3.22 & 0.02 & 0.13 & 0.01 \\
Age & 43.35 & 43.04 & 0.31 & 0.28 & 0.02 \\
Female & 0.15 & 0.13 & 0.02 & 0.84 & 0.05 \\
Income (1000 HUF) & 1023.58 & 1035.19 & -11.61 & -0.30 & -0.02 \\
Consumption to income & 0.83 & 0.82 & 0.01 & 0.33 & 0.03 \\
Food exp. to income & 0.20 & 0.21 & -0.00 & -0.26 & -0.02 \\
Payment to income & 0.15 & 0.15 & -0.00 & -0.05 & -0.00 \\
Have liquid assets & 0.08 & 0.10 & -0.01 & -0.37 & -0.03 \\
Capital & 0.15 & 0.11 & 0.04 & 1.22 & 0.09 \\
County capital & 0.23 & 0.32 & $-0.09+$ & -1.86 & -0.14 \\
Town & 0.30 & 0.33 & -0.03 & -0.77 & -0.05 \\
Village & 0.32 & 0.24 & $0.08^{*}$ & 2.07 & 0.13 \\
\hline
\end{tabular}

Notes: This table presents the average characteristics of treatment (FC debtor) and control (LC debtors) households for the propensity score matched sample. The Normalized Difference is defined as $\frac{\bar{X}_{1}-\bar{X}_{0}}{\sqrt{V_{1}+V_{0}}}$, where $\bar{X}_{\omega}\left(V_{\omega}\right)$ is the sample average (variance) for the treatment and control groups, as defined in Imbens and Wooldridge (2009). 
Table A.6: Balancedness for propensity score matched sample, LC debtors and nondebtors as controls

\begin{tabular}{lccccc}
\hline & Treatment & Control & $\begin{array}{c}\text { Treatment- } \\
\text { Control } \\
\text { Diff. }\end{array}$ & t-statistic & $\begin{array}{c}\text { Normalized } \\
\text { Diff. }\end{array}$ \\
\hline Primary school & 0.14 & 0.12 & 0.02 & 1.13 & 0.04 \\
Vocational school & 0.42 & 0.40 & 0.02 & 0.68 & 0.03 \\
High school & 0.29 & 0.33 & -0.04 & -1.42 & -0.06 \\
College & 0.15 & 0.15 & -0.00 & -0.01 & -0.00 \\
Household size & 3.22 & 3.18 & 0.04 & 0.48 & 0.02 \\
Age & 44.01 & 45.19 & -1.18 & -1.62 & -0.07 \\
Female & 0.17 & 0.17 & 0.00 & 0.17 & 0.01 \\
Income (1000 HUF) & 1053.90 & 1017.08 & 36.81 & 1.32 & 0.06 \\
Consumption to income & 0.83 & 0.85 & -0.02 & -0.97 & -0.04 \\
Food exp. to income & 0.20 & 0.22 & $-0.02^{* *}$ & -3.03 & -0.13 \\
Have liquid assets & 0.08 & 0.12 & $-0.05^{*}$ & -2.54 & -0.11 \\
Capital & 0.16 & 0.19 & -0.03 & -1.10 & -0.05 \\
County capital & 0.23 & 0.25 & -0.02 & -0.89 & -0.04 \\
Town & 0.30 & 0.27 & 0.03 & 1.32 & 0.05 \\
Village & 0.31 & 0.29 & 0.02 & 0.60 & 0.03 \\
\hline
\end{tabular}

Notes: This table presents the average characteristics of treatment (FC debtor) and control (LC debtors and non-debtors) households for the propensity score matched sample. The Normalized Difference is defined as $\frac{\bar{X}_{1}-\bar{X}_{0}}{\sqrt{V_{1}+V_{0}}}$, where $\bar{X}_{\omega}\left(V_{\omega}\right)$ is the sample average (variance) for the treatment and control groups, as defined in Imbens and Wooldridge (2009).

Table A.7: Price and quality adjustment using alternative decomposition of the intensive margin

\begin{tabular}{lcccccc}
\hline & Total expenditures & \multicolumn{2}{c}{ Intensive } & & \multicolumn{2}{c}{ Intensive } \\
\cline { 3 - 4 } & & $\begin{array}{c}\text { Laspeyres } \\
\text { price }\end{array}$ & $\begin{array}{c}\text { Paasche } \\
\text { quantity }\end{array}$ & & $\begin{array}{c}\text { Paasche } \\
\text { price }\end{array}$ & $\begin{array}{c}\text { Laspeyres } \\
\text { quantity }\end{array}$ \\
\hline FC $\times$ Post & $-23977.09^{* *}$ & $-5824.22+$ & $-12403.05^{*}$ & & $-4756.16+$ & $-12403.05^{*}$ \\
& $(9253.20)$ & $(3123.27)$ & $(5834.47)$ & & $(2757.68)$ & $(5834.47)$ \\
Observations & 39689 & 39689 & 39689 & & 39689 & 39689 \\
Percent of total & - & $24.29 \%$ & $51.72 \%$ & & $19.83 \%$ & $51.72 \%$ \\
\hline
\end{tabular}

Notes: This table reports the estimated effect of FC debt exposure 


\section{B Data appendix}

\section{B.1 Household debt}

Determining the currency denomination of debt We have two sets of information on household debt. First, every year households are surveyed about whether they have debt obligations. From this we know whether they have debt obligations, the year of borrowing, the amount borrowed, the maturity of debt, and the monthly installment.

From 2009, households are also surveyed about their housing debt. This gives us information on whether they have housing debt, the type of debt (mortgage vs home equity), year of origination, the currency denomination of debt (with information also on the conversion), the total amount payed in the year as installment, and whether any of the household members have another loan from a financial institution.

To determine the currency denomination we exploit that households borrowed in local currency only before the end of 2004, and mostly in Swiss franc after 2004 (see Figure 2).

Annuity model We calculate households' debt burdens by using loan characteristics: the year of origination, maturity, type of loan and currency denomination.

With this information we use an annuity formula to impute the monthly payment and remaining balance for each loan. Specifically, for each loan $i$ in currency $c$ of type $k$ originated at time $t_{0}$ with maturity $m$ and remaining periods $n=t_{0}+m-t+1$, we denote the imputed values of the monthly payment and remaining loan balance as $\tilde{P}_{i t}$ and $\tilde{D}_{i t}$. These are computed as

$$
\begin{aligned}
& \tilde{P}_{i t}=\tilde{D}_{i t}\left(\frac{1-R_{c k m t}^{-n}}{R_{c k m t}-1}\right)^{-1} \\
& \tilde{D}_{i t}=\tilde{D}_{i, t-1} \cdot R_{c k m, t-1}-P_{i, t-1},
\end{aligned}
$$

where $D_{i t_{0}}=\tilde{D}_{i t_{0}}$ is the originated amount. $R_{c k m t}$ is the average monthly gross interest rate charged for that specific loan product (currency, loan type) in period $t$.

This formula hence calculates the sequence of payments and outstanding debt that we would observe in the absence of default, assuming that loan $i$ pays the average variable rate charged for that loan product. We do not believe that the assumption that loans remain current is severe drawback for this methodology because default rates were very low before the 2008 crisis (see Figure A.2). ${ }^{37}$

High liquidity proxy We proxy household liquidity positions by whether a household can cover an unanticipated expenditure shock of the size of their monthly net income from their own savings. Specifically, we two use questions on whether the household can cover a large unexpected expenditure shock from own savings and the maximum amount it can cover. We define high liquidity households to be those who can cover an unanticipated expenditure shock at least their monthly net income.

\footnotetext{
${ }^{37}$ Statistics from the National Bank of Hungary show that the fraction of non-perfor ming loans was below
} 
Table B.8: Variables on household debt

\begin{tabular}{|c|c|c|c|c|c|c|c|c|}
\hline \multirow[b]{2}{*}{ Variable name } & \multicolumn{8}{|c|}{ Year of wave } \\
\hline & 2005 & 2006 & 2007 & 2008 & 2009 & 2010 & 2011 & 2012 \\
\hline \multicolumn{9}{|c|}{ Asked when questions are about the apartment characteristics } \\
\hline Has housing loan & $\mathrm{Y}$ & $\mathrm{Y}$ & $\mathrm{Y}$ & $\mathrm{Y}$ & $\mathrm{Y}$ & $\mathrm{Y}$ & $\mathrm{Y}$ & $\mathrm{Y}$ \\
\hline Borrowed amount & $\mathrm{Y}$ & $\mathrm{Y}$ & $\mathrm{Y}$ & $\mathrm{Y}$ & $\mathrm{Y}$ & Y & Y & Y \\
\hline Year of origination & $\mathrm{Y}$ & $\mathrm{Y}$ & $\mathrm{Y}$ & $\mathrm{Y}$ & $\mathrm{Y}$ & Y & $\mathrm{Y}$ & Y \\
\hline Maturity & $\mathrm{Y}$ & Y & Y & $\mathrm{Y}$ & $\mathrm{Y}$ & Y & Y & Y \\
\hline \multicolumn{9}{|c|}{ Asked when questions are about collateralized debt } \\
\hline Has housing loan & & & & & $\mathrm{Y}$ & $\mathrm{Y}$ & $\mathrm{Y}$ & $\mathrm{Y}$ \\
\hline What is the collateral & & & & & $\mathrm{Y}$ & $\mathrm{Y}$ & $\mathrm{Y}$ & $\mathrm{Y}$ \\
\hline Type of loan (mortgage vs home eq) & & & & & $\mathrm{Y}$ & $\mathrm{Y}$ & $\mathrm{Y}$ & $\mathrm{Y}$ \\
\hline Year of origination & & & & & $\mathrm{Y}$ & $\mathrm{Y}$ & $\mathrm{Y}$ & $\mathrm{Y}$ \\
\hline Currency denomination & & & & & $\mathrm{Y}$ & Y & Y & $\mathrm{Y}$ \\
\hline Total payment in the year & & & & & $\mathrm{Y}$ & Y & & \\
\hline Monthly payment & & & & & & & $\mathrm{Y}$ & $\mathrm{Y}$ \\
\hline Household has other types of loans & & & & & $\mathrm{Y}$ & $\mathrm{Y}$ & $\mathrm{Y}$ & $\mathrm{Y}$ \\
\hline Questions on personal, car, etc. loans & & & & & $\mathrm{Y}$ & $\mathrm{Y}$ & $\mathrm{Y}$ & $\mathrm{Y}$ \\
\hline Delinquent loan due to cash shortage & & & & & $\mathrm{Y}$ & $\mathrm{Y}$ & Y & $\mathrm{Y}$ \\
\hline
\end{tabular}

\section{B.2 Alternative indices for decomposing the intensive margin}

In the main analysis, we used the Marshal-Edgeworth index for the decomposition, here we discuss alternative indices for decomposition. In particular, we use the Laspeyres, Paasche and Fisher indices.

The intensive margin of the change in expenditures can be decomposed as the following:

$$
\begin{aligned}
\sum_{j \in J_{t / t-1}} e_{j t}-\sum_{j \in J_{t / t-1}} e_{j, t-1} & =\sum_{j \in J_{t / t-1}} p_{j t} q_{j t}-\sum_{j \in J_{t / t-1}} p_{j, t-1} q_{j, t-1}= \\
& =\underbrace{\sum_{j \in J_{t / t-1}} \Delta p_{j t} q_{j, t-1}}_{\text {Laasche price change }}+\underbrace{\sum_{\text {Laspeyres change }} \Delta q_{j t} p_{j t}}_{\text {Laspeyres quantity change }} \\
& =\underbrace{\sum_{j \in J_{t / t-1}}^{j \in J_{t / t-1}} \Delta p_{j t} q_{j t}}_{\text {Paasche quantity change }}+\underbrace{\sum_{j=1}}_{\sum_{j \in J_{t / t-1}} \Delta q_{j t} p_{j, t-1}}
\end{aligned}
$$

The Laspeyres price change uses the quantities from $t-1$ as weights, while the Paasche price index uses the quantities from $t$. This implies that the Laspeyres index is likely to overstate the change in prices as it does not account for the fact that households can change the quantities. The opposite is true for the Paasche index.

1 percent for both local currency loans and foreign currency housing loans in 2008Q3. 
Figure B.9: Calculated annuity payment and reported payment comparison
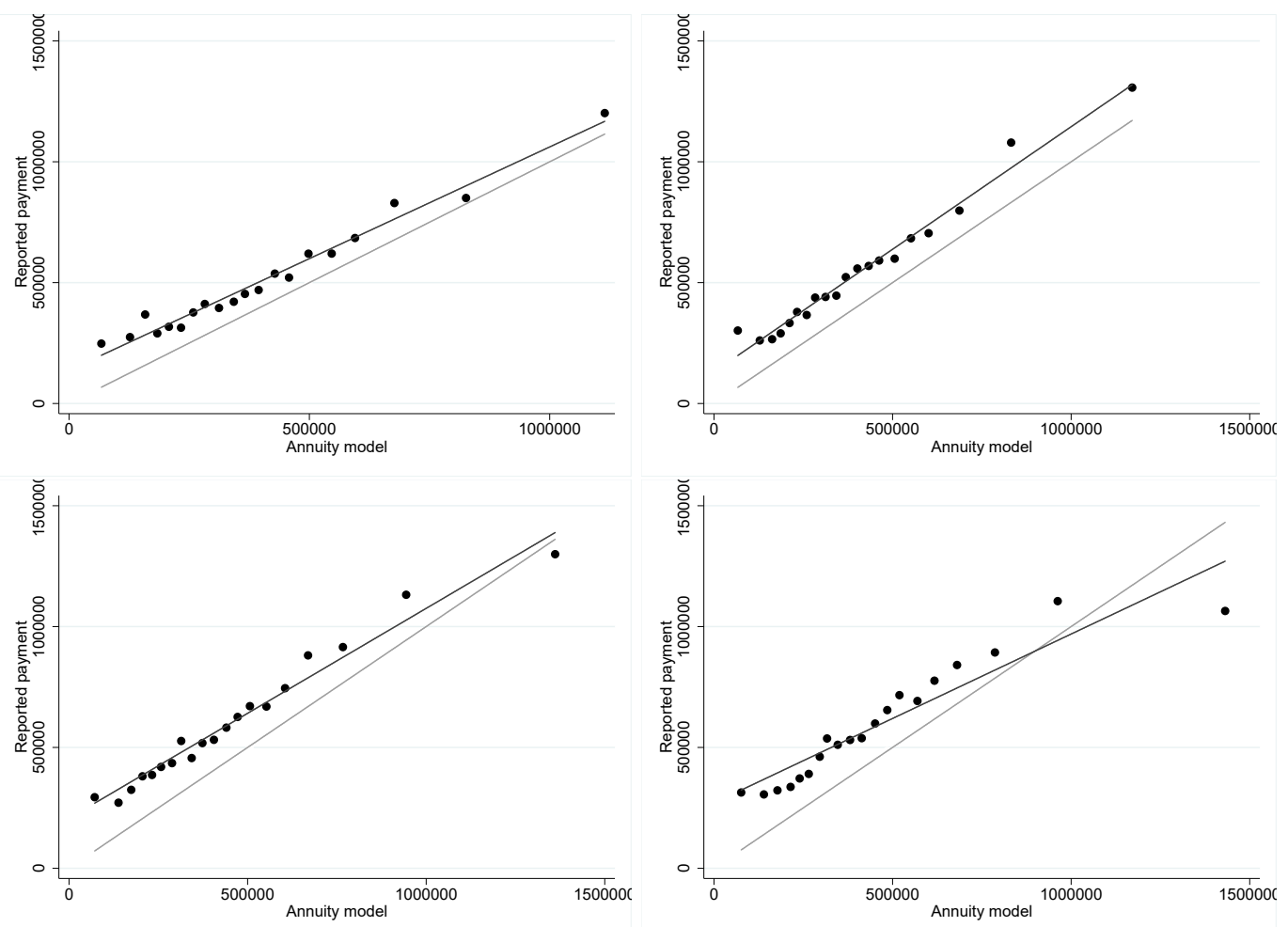

Notes: The figures show the calculated annuity payment and the reported payment by households in 2009 (top left), 2010 (top right), 2011 (bottom left), and 2012 (bottom right). 
Figure B.10: Average individual exposure at the locality level vs administrative exposure

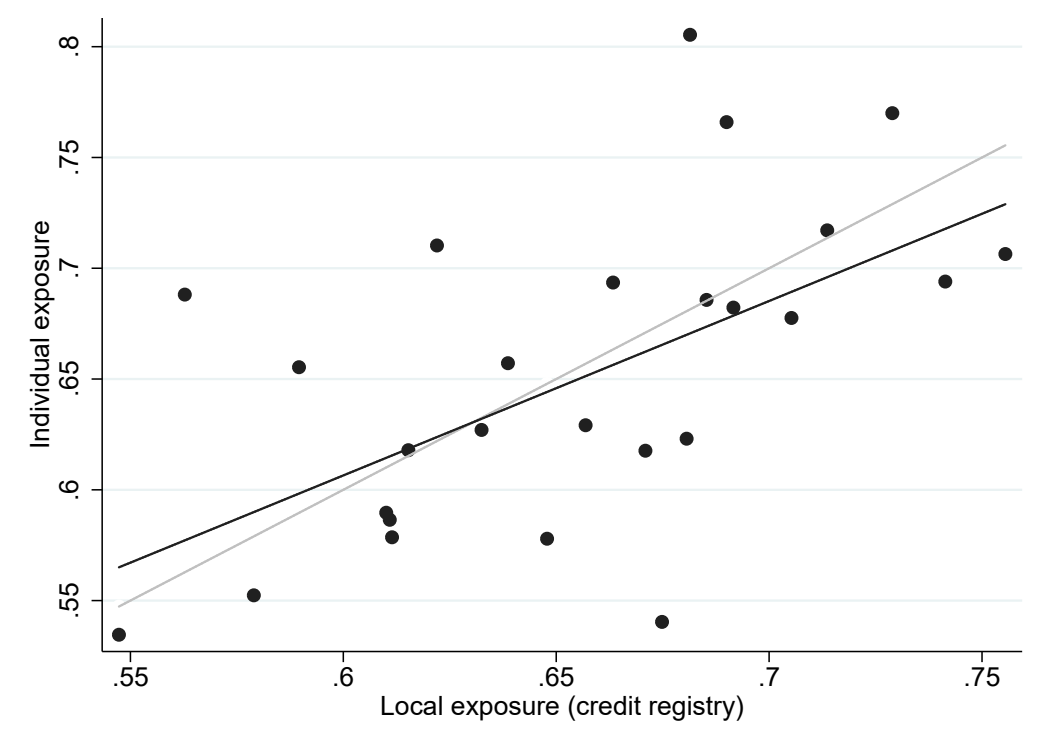

Notes: This figure presents a binscatter of local FC debt exposure in the household credit registry with individual-level exposure from the household consumption survey. 


\section{Foreign Currency Lending to Households in Other Contexts}

This appendix provides additional examples of episodes where household foreign currency debt left households and banks exposed to adverse balance sheet effects. We discuss both episodes captured in Figure 1 and narrative accounts from other episodes where data is not available.

Argentina In Argentina during its crisis and devaluation in 2002, 80\% of mortgages were denominated in dollars, while earnings of borrowers with dollar debt was mainly in pesos (IMF, 2003a). Many Argentine homeowners fell behind on mortgage payments after the devaluation (Weisbrot and Sandoval, 2007). The adverse balance sheet effects from the devaluation led to a forceful and disruptive policy of "pesofication" to convert assets and liabilities into pesos, which benefitted dollar debtors relative to dollar depositors (Kiguel, 2011; Halac et al., 2004). ${ }^{38}$

Azerbaijan Following Azerbaijan's devaluation in 2015, consumers with dollar debts saw installments rise by over one-third, resulting in financial distress and bank loan losses (Fitch, 2015; IWPR, 2015).

The Baltics Estonia, Latvia, and, to a lesser extent, Lithuania also saw significant FC lending to households in the 2000s. Latvia provides an example of an economy with widespread foreign currency debt during a severe bust and balance-of-payments crisis where policy maintained a currency peg and pursued an internal devaluation (Blanchard et al., 2013). Devaluation of the Latvian currency was eschewed in part because of the risk of insolvencies from widespread foreign currency debt exposures.

Austria During the mid-2000s, 12 percent of Austrian households reported having a Swiss franc or Japanese yen loan. In 2007, one-third of new lending to households was FC-denominated. In Austria, this exposure was concentrated among higher-income and risk-loving households (Beer et al., 2010).

Central and Eastern Europe As with the case of Hungary examined in this paper, foreign currency (often Swiss franc) lending to households was widespread during the 2000s in emerging European economies, including Bulgaria, Croatia, Poland, Serbia, Slovenia, Romania, and Ukraine (e.g., Rosenberg and Tirpák, 2008). This resulted in financial distress for foreign currency debtors, rising non-performing loans, and years of legal disputes about the resolution of these debts. In Poland, for example, legal risks associated with FC mortgages originated before the 2008 financial crisis remained a threat to financial stability in 2021 (Reuters, 2021).

\footnotetext{
${ }^{38}$ Deposits were "pesofied" at 1.4 pesos/dollar (well below market rates), while bank loans in FC were converted to pesos at the highly favorable 1 peso/dollar rate.
} 
Greece Approximately 70,000 households in Greece borrowed in Swiss francs during the 2000s, especially between 2006 and 2010. This resulted in adverse balance sheet effects when the Swiss franc appreciated against the euro starting in 2010. The Greek Supreme Court Ruled in 2019 that borrowers would have to repay loans in full.

Iceland During Iceland's banking and currency crisis in 2008, about $20 \%$ of household loans were in foreign currency (often in Swiss franc and Japanese yen), up from less than 5 percent in the early 2000s, and many households did not have foreign currency income. Furthermore, almost all mortgages were indexed to inflation and thereby indirectly exposed to devaluation risk. This drove borrowers toward insolvency, and these debts were subsequently aggressively restructured (Benediktsdóttir et al., 2017).

Mexico Mexico's sudden stop and currency crisis in 1994-95 was preceded by rapid lending growth to households (Musacchio, 2012; Müller and Verner, 2021). These loans were often denominated in foreign currency or had floating rates that adjusted monthly and led to sharp increases in installments with the spike in interest rates that followed the collapse of the peso (Karaoglan and Lubrano, 1995; Corsetti et al., 1999). The devaluation of the peso resulted in rising non-performing loans and financial distress for these indebted households.

Peru The Peruvian exchange rate depreciated significantly (about 25 percent) against the dollar from mid-2013 to 2016 onward, following the Taper Tantrum (Humala, 2019). Despite sustained de-dollarization, especially for household loans, about 34 percent of mortgage loans were still denominated in dollars in 2014 (IMF, 2015). ${ }^{39}$ The macro-financial risks from foreign currency household debt in this episode were contained, although 15 percent of debtors, mostly high-income households, had elevated debt-to-income ratios (IMF, 2016).

Russia At the onset of the Global Financial Crisis, about 13 percent of household credit in Russia was FC-denominated (mainly dollar), leading to higher default rates on FC household loans with the depreciation of the ruble (Sprenger and Urošević, 2011). Before the 2014 depreciation of the ruble, the share of household debt in FC declined substantially, and estimates of the number of FC mortgage holders ranged from 25,000 to $150,000 .{ }^{40}$ While this represented a small minority of borrowers, the 2014 depreciation of the ruble more than doubled domestic currency installments on dollar loans and led to severe financial distress for many FC borrowers, as well as protests demanding loan restructuring (Business Insider, 2014).

\footnotetext{
${ }^{39}$ The Peruvian financial system has been highly dollarized following instability and hyperinflation in the 1970s and 1980s, although efforts at de-dollarization had gradually lowered the share of dollar loans and deposits (IMF, 2015).

${ }^{40}$ Based on data from the Central Bank of Russia, by 2014 only 2.5 percent of household debt was denominated in FC in 2013.
} 
Uruguay Uruguay's devaluation in 2002 resulted in an 89 percent increase in the dollar exchange rate. The financial system was highly dollarized, both in terms of credit and deposits. In 2002, 87 percent of bank lending was FC-denominated (IMF, 2003b). Some households with dollar debt experienced a doubling in debt payments (e.g., NYT, 2002). 


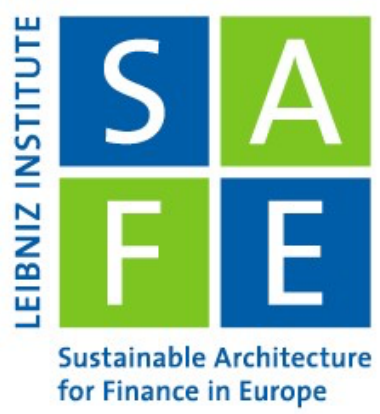

\section{Recent Issues}

No. 331 Ruggero Jappelli, Loriana Pelizzon, Alberto Plazzi

No. 330 Jan Krzyzanowski, Uwe Walz

No. 329 Jana Eisenkopf, Steffen Juranek, Uwe Walz

No. 328 Hoang Ha Nguyen Thi, Alfons Weichenrieder

No. 327 Fincap team

No. 326 Wenhui Li, Peter Ockenfels, Christian Wilde

No. 325 Alperen A. Gözlügöl

No. 324 Massimiliano Caporina, Michele Costola

No. 323 Alexandre Corhay, Thilo Kind, Howard Kung, Gonzalo Morales

No. 322 Gianluca Anese, Marco Corazza, Michele Costola, Loriana Pelizzon

No. 321 Ignazio Angeloni, Johannes Kasinger, Chantawit Tantasith

No. 320 Sebastian Steuer, Tobias H. Tröger

No. 319 Erik Theissen, Christian Westheide

No. 318 Kevin Bauer, Michael Kosfeld, Ferdinand von Siemens
The Core, the Periphery, and the Disaster: Corporate-Sovereign Nexus in COVID-19 Times

Bank Regulation, Lending and Patenting: Evidence from the EBA Capital Exercise

Responsible Investment and Stock Market Shocks: Short-Term Insurance and Persistent Outperformance Post-Crisis?

C and S Corporation Banks: Did Trump's Tax Reform Lead to Differential Effects?

Non-Standard Errors

The Effect of Ambiguity on Price Formation and Trading Behavior in Financial Markets

The Clash of 'E' and 'S' of ESG:

Just Transition on the Path to Net Zero and the Implications for Sustainable Corporate Governance and Finance

Time-Varying Granger Causality Tests for Applications in Global Crude Oil Markets: A Study on the DCC-MGARCH Hong Test

Discount Rates, Debt Maturity, and the Fiscal Theory

Impact of Public News Sentiment on Stock Market Index Return and Volatility

The Geography of Banks in the United States (1990-2020)

The Role of Disclosure in Green Finance

Call of Duty: Designated Market Maker Participation in Call Auctions

Incentives, Self-Selection, and Coordination of Motivated Agents for the Production of Social Goods 